Portland State University

PDXScholar

1985

\title{
Wilhelm Reich's Character analysis in its historical context
}

R. Daniel McCauley

Portland State University

Follow this and additional works at: https://pdxscholar.library.pdx.edu/open_access_etds

Part of the Intellectual History Commons, and the Psychoanalysis and Psychotherapy Commons Let us know how access to this document benefits you.

\section{Recommended Citation}

McCauley, R. Daniel, "Wilhelm Reich's Character analysis in its historical context" (1985). Dissertations and Theses. Paper 3593.

https://doi.org/10.15760/etd.5477

This Thesis is brought to you for free and open access. It has been accepted for inclusion in Dissertations and Theses by an authorized administrator of PDXScholar. Please contact us if we can make this document more accessible: pdxscholar@pdx.edu. 
AN ABSTRACT OF THE THESIS OF R. Daniel McCauley for the Master of Arts in History presented December 4, 1985.

Title: Wilhelm Reich's Character Analysis in its Historical Context.

APPROVED BY MEMBERS OF THE THESIS COMMITTEE:

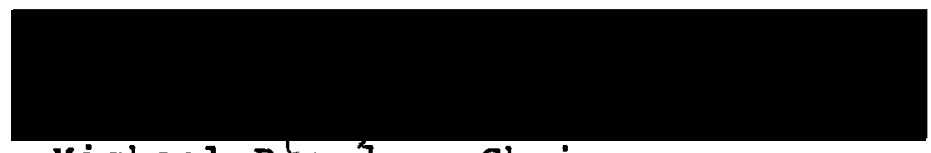

Michael Rèardon, Chairman

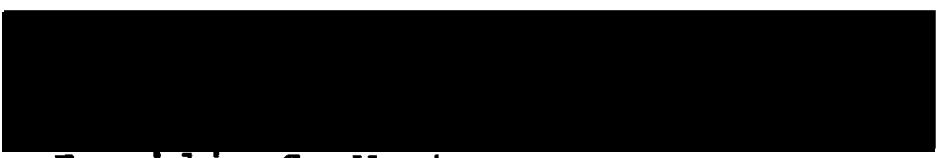

Franklin C. West
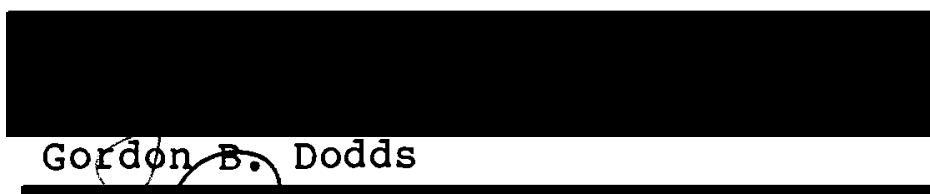

The thesis is an attempt to reconcile contradictions and devise historical meaning from a problematic text. The book is Wilhelm Reich's Character Analysis, first published in 1933. This influential psychoanalytic work embodies both a radical social theory and disturbing authoritarian attitudes. The thesis uses a variety of methodologies, in particular Roland Barthes' techniques for ascribing 
historical meaning to certain formal qualities of writing. The thesis proceeds from a summary of methodological studies in intellectual history and criticism, including those of $I$. A. Richards, R. G. Collingwood, and Dominick LaCapra, as well as Barthes, to a description of Character Analysis and its various historical contexts - biographical, social, and intellectual. The thesis relies on the authoritative biography of Reich, by Myron Scharaf, on autobiographical accounts by Reich's wife and son, on other texts in psychoanalytic social theory by Erik Erikson, Erich Fromm, Herbert Marcuse, Georges Bataille, and Max Horkheimer, and on secondary scholarship on the origins of National Socialist ideology. The thesis argues that despite the influence of reactionary tendencies in Reich's personality and cultural and social milieu, character Analysis remains a valuable work in the development of a convincing theory of liberation. 


\title{
WILHELM REICH'S CHARACTER ANALYSIS
}

IN ITS HISTORICAL CONTEXT

by

R. DANIEL MCCAULEY

A thesis submitted in partial fulfillment of the requirements for the degree of

\author{
MASTER OF ARTS \\ in \\ HISTORY
}

Portland State Univerisity

1986 
TO THE OFFICE OF GRADUATE STUDIES AND RESEARCH:

The members of the committee approve the thesis of R. Daniel McCauley presented December 4, 1985 .

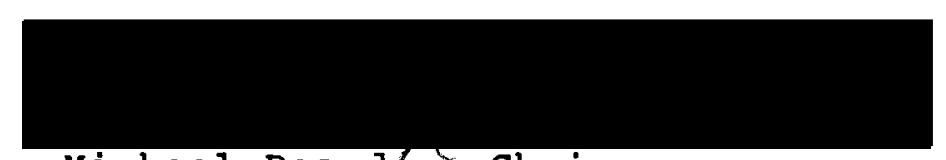

Michael Reardón, Chairman

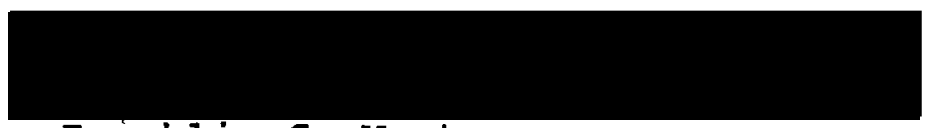

Franklin C. West

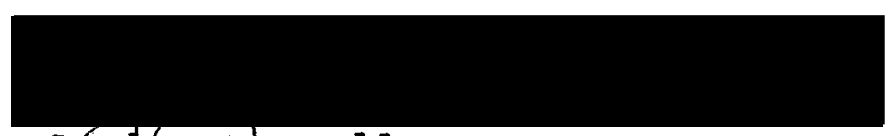

Gor $\not b$ n B Dodds

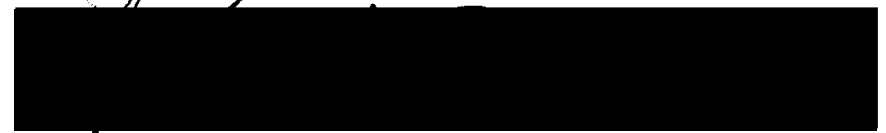

Robert Shotola

APPROVED :

Bernard V. Burke, Head, Department of History

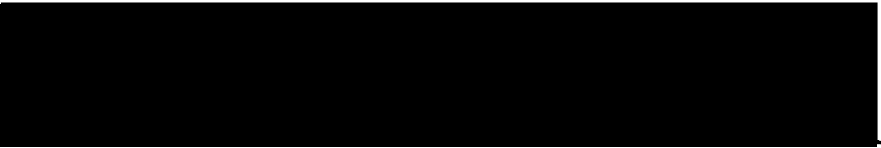

Bernard Ross, Dean of Graduate Studies and Research 


\section{TABLE OF CONTENTS}

I INTRODUCTION......................... 1

II METHODOLOGY...................... 7

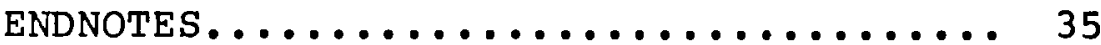

III BIOGRAPHY AND TEXT.................. 38

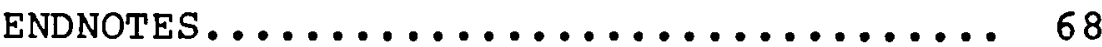

IV GENERATION AND FIELD OF DISCOURSE....... $7 \emptyset$

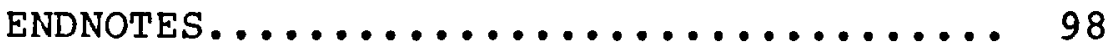

V CONCLUSION...................... 191

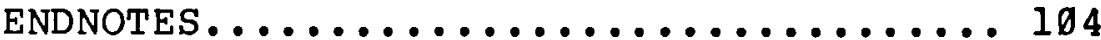

BIBLIOGRAPHY....................................... 195 


\section{CHAPTER I}

\section{INTRODUCTION}

This essay is an exercise in eliciting meaning from a text. The book is character Analysis, written by wilhelm Reich over the years 1925 to 1948. It is a classic of depth psychology and radical social theory. The significance of Reich's work lies in his advancing a conception of mind which subsumes both physiological processes and social life into an integrated theory of reason; and which also reconciles the complex, contestatory discourses of psychoanalysis and communism. It is a theory in the process of development, and the text reflects this. A fragment, describing a decade of clinical work and political activity, was first published by Sexpol-Verlag in Berlin in 1933 as characteranalyse. The final expanded edition appeared in New York in English in 1949. This contains clarifications in the forms of notes, reminiscences, polemics, new clinical studies, and innovations in terminology.

I have chosen to discuss this particular book not only because of its philosophical significance, but also its affect. It is moving and convincing in peculiar ways. First, Reich has written Character Analysis with a passionate commitment to rationality; and he has applied 
this to unmasking a compelling mystery - the interrelationship among sexual repression, sadomasochism, madness, and unfreedom. Also, in the course of his argument, he often surprises, disorients, and presents problems to the reader. This is partly due to the author's implicating diverse types of writing and intentions. Formally, Character Analysis is at once a wide-ranging theory and a pastiche; so shocks and disjunctures appear in the course of the text. For example, Reich's basic concern is to encourage psychoanalysts to adopt a controversial technique; this is to attack at a certain point in therapy not the words and the memories their patients carry of the past, but their present demeanor, manners, physical bearing, their very bodies, and, above all, their sexual abstinence. And he pursues what appears to be a strictly scientific argument here. But this rigorous discourse opens onto an intensely dramatic and personal narrative - the case study of his attempt to cure a young shizophrenic; at other moments onto an utopian communique - a metapsychological prescription against oppression and conflict; and even onto an image of transcendence - of the structure and purpose of the cosmos. Another aspect of the strange appeal of this text is its luridness. At its center, Reich has placed a complex of assertions about sexual orgasm, which includes such relatively inappropriate statements as clinical descriptions, boasts and confessions, idealizations, and 
dicta for politically correct sex acts. On occasion, these seem to the reader attempts to map out a strategy for the scientific and ideological domination of the most private behavior. Reich also writes in Character Analysis with a generous respect for the experiences and opinions of psychotics; indeed, he has the disturbing knack to bring both himself and his reader into collusion with his patients' madness. And finally, the argument of character Analysis comes to seem to this reader quite fantastic, while still maintaining its conviction and importance. The text is writing that, by its virtues, its rigor, universality, ambition, and radicalness, is at once self-destructive and liberating. All these are compelling reasons for examining and amplifying Reich's text in an effort to understand it.

I hope to elucidate these aspects of character Analysis by situating the book historically. This is only indirectly an attempt to trace the influences on the text, its intellectual and social determinants, or its general impact. Instead, I want to attempt a more limited, perhaps personal, kind of historical understanding of Character Analysis by comparing similarities and differences between it and analogous pieces of writing. I have selected these additional texts also for their personal affect, as well as for their common concerns, modes of expression, and relationship in time to Character Analysis. They include, for example, Max Horkheimer's Eclipse of Reason, which 
parallels Reich's effort to understand the political and social crises of the twentieth century from a psychoanalytic perspective; Reich's own Mass Psychology of Fascism, which was written concurrently with Character Analysis and clarifies the sociological and political aspects of his work; and Ilse ollendorff Reich's biography, which documents her husband's experiences and intentions.

This comparison of texts will hopefully evoke meaning because they share a climate of opinion, a world-view. They are bound together by their relationship in time as well as their similar concerns into a field of discourse. These other writings compose a temporally illumined scheme of contexts within which Character Analysis might be placed. This scheme includes one context made up of statements about Reich's experiences and intentions; another of statements that can be arranged into the tradition of discourse within which Reich wrote, which includes the psychoanalytic and Marxist critiques of fascism; and one of statements which impinge referentially or instrumentally upon common institutions, political events, and other facts of social life. The historical meaning of Character Analysis resides where it and these contexts intersect.

But gaps, disjunctures, both in Reich's writing and this field of discourse, are also meaningful. The variety of critical perspectives on fascism creates an often conflicting textual milieu. And as far as texts refer to 
moments outside themselves, to events and institutions that have concrete existence, these exist and endure, and also change and disappear within any historical period. So some possibilities for meaning, certain relationships between statements, are complex and fractured. Horkheimer's discussion of the relationship between psychological needs, reason, and forms of political domination made different sense in 1947, after the war against fascism, than Reich's in 1934, in the midst of revolution. They take on still additional significance from the perspective of the present -while for two decades unrestrained narcissism has been a practical form of resistance to racism, militarism, and the fragmentation of love into commodity relationships. of course, both writers' statements still connect with one another. They are part of a continuing radical discourse about reason, society, and human nature. Also, Character Analysis was written in confrontation to other texts and real events. It was the culmination of disputes with both psychoanalysts and socialists. And finally, Reich wrote it with instrumental intent - to make things happen in the world, sometimes fantastic, utopian, absurd things, absolutely contrary to the commonplace sense of reality. He attempted to argue the world he desired into being. This tends to appear to the reader as the criticism of many political, psychoanalytic, and scientific ideas as forms of domination. Consequently, these gaps, extensions, open 
spaces in the field of textual statements have meaning as potential sites of empowerment. In his text, Reich seizes upon contradictions, whether between Marxist and Freudian theory and practice, between basic human needs and the experience of living in Central Europe in the 1930's, between reason and conventional constraints, within bodies which function against themselves, or within a madness that makes sense, as opportunities for liberation, for dispersions and redistributions of power. And this, too, is historically meaningful. 
CHAPTER II

METHODOLOGY

Before proceeding to describe Character Analysis more closely, I want to review some current opinions on the status of the methodology of the history of ideas and the criticism of significant texts, and clarify what I intend by historical meaning. For $I$ am using a number of disparate notions from twentieth century writers, from R. G. Collingwood to Roland Barthes, as well as Reich's own sense of the relationship among mind, memory, the past, and present concerns. These various notions do share, however, a conviction about the extent to which historical thinking is autonomous. It is a kind of fiction or poetics that is made meaningful by the historian's imaginative power. This includes her or his abilities to enclose the past in its relevance or its distance, to invest the present with qualities of mind, and to visualize the future with hope. History is, at least in part, determined by the status of the historian as his own subject.

For example, Collingwood argues in the Idea of History that any intellectual historian's knowledge of the past is necessarily based on an assumption about the unity of human thought. This concept is an ancient and pervasive one. 
Collingwood translates its classical formulation into terms of the logical dependence of present mental acts on previous ones, of a chain of ideation through time.

Ever since Plato in the Timaeus said that time is the moving image of eternity, philosophers have for the most part agreed that there was some relation between [time and reason and the] necessary sequence by which one thing leads to another in a non-temporal logical series. If this is denied, and if it is maintained that temporal sequence and logical implication have nothing to do with each other, historical knowledge becomes impossible, for it follows that we can never say about any event "this must have happened"; the past can never appear as the conclusion of a logical inference. If the temporal series is a mere aggregate of disconnected events, we can never argue back from the present to the past. But historical thinking consists precisely of arguing back in this way; and it is therefore based on the assumption that there is an internal or necessary connection between the events of a time-series such that one event leads necessarily to another and we can argue back from the second to the first. On this principle there is only one way in which the present state of things can have came into existence, and history is the analysis of the present in order to see what this process must have been. 1

With Collingwood, historical thinking is validated on a similar, but somewhat more limited, logical basis. For the historian, the present shares an identity with the past as the certain sum or composite of a continuum of moments, but distilled to acts of pure mind. Collingwood proceeds to acknowledge favorably the view of his contemporary, the political theorist Michael Oakeshott, that historical thinking is thus "a perfectly genuine experience." what the historian

Is experiencing is going on in his mind now; in so far as he places it, as it were, at arm's length from him in the past, he is misconceiving it; he is arranging in imaginary pigeon-holes of past time what is actually all present and not past at all. And this does not imply that he is making 
historical mistakes about the past. There is no past, except for a person involved in the historical mode of experience; and for him the past is what he carefully and critically thinks it to be. He makes no mistake qua historian: the only mistake he makes is the philosophical mistake of arranging in the past what is actually all present experience.....

[This] entirely vindicates the autonomy of historical thought. The historian is master in his own house; he owes nothing to the scientist or to anyone else. And this house is not built and furnished out of mere ideas of his own which may or may not correspond with the ideas of other historians or with the real past which they are all alike trying to know; it is a house inhabited by all historians, and it consists not of ideas about history, but of history itself. 2

History, then, is radically contemporary; it is created; it is always what the historian makes it; and it is meaningful in the sense it shares a continuously renewed identity with all acts of mind.

Historical knowledge is the knowledge of what mind has done in the past, and at the same time it is the redoing of this, the perpetuation of past acts in the present. Its object is therefore not a mere object, something outside the mind which knows it; it is an activity of thought, which can be known only in so far as the knowing mind reenacts it and knows itself as so doing. To the historian, the activities whose history he is studying are not spectacles to be watched, but experiences to be lived through in his mind; they are objective, or known to him, only because they are also subjective, or activities of his own. 3

Collingwood's view tends to minimize the factness of the past. History is possible as the sympathetic repetition of thought events. It is imbued with meaning by the unity of reason, by a basic identity of human thought throughout time. But it is primarily an act of imagination, performed with presence and presentness of mind.

These dicta on the logic of historical thinking are 
related to one significant aspect of what has most commonly been written in this century as the history of ideas. The typical intellectual historian constructs a line of development through past facts and ideas toward some more contemporary and relevant theory, viewpoint, or taste. Rudolph $\mathrm{H}$. Weingartner clarifies this tradition in "Some Philosophic Comments on Cultural History." Weingartner has chosen "fairly arbitrarily" three texts: Edwin E. Lowinsky, "Awareness of Tonality in the sixteenth Century", 1961; Herbert Butterfield, "The History of the Modern Theory of Gravitation", 1952; and Arthur 0. Lovejoy, "The First Gothic Revival and the Return to Naturen, 1932. He summarizes "the historical substance" of each of these briefly. He then proceeds "to discuss the nature of the subject matter of each of the samples", "to focus on the types of connection said by [these] historians to hold among the different elements of their subject matter", and to "take up the problems of causality and influence in cultural and intellectual history." 4

His basic observation of the subject matter of these texts is that they are only minimally concerned with ordinary actions or events, but instead with what the products of various $k$ inds of intellectual activity look like; that is, they are concerned with similarities and differences among ideas. These historical accounts do not touch upon the usual concomitants of activity - neither 
individual motives, psychology, and aims, nor daily and professional life. Weingartner suggests that such disinterest by these writers in character and the conditions of work, but exclusive emphasis on formal descriptions of certain special features of the works themselves, indicate an unusual view of causality.

The formal relationships these intellectual historians describe among various ideas are complex. But they are all viewed from the standpoint of the present. Both Butterfield and Lowinsky are interested in abstract conceptions that predate and resemble certain currently admired ideas, specifically, Newton's cosmology and the tonalities of the classical canon from Bach to Beethoven. Lovejoy selects statements about design and nature that compose a unified correct taste. And he proceeds to describe a relationship between a change in taste and a change in the meaning of the concept of nature. Lowinsky describes an advance in musical composition in the sixteenth century, an increase in the number and complexity of triadic harmonies over time. He also categorizes these formal elements against those of another competing development of chromaticism. Butterfield describes how the work of a century of individual scientists provided a variety of propositions and methods that Newton was able to select out and bring together into a universal theory of matter and motion.

Weingartner insists that the historians cannot mean 
these relationships among the formal aspects of individual intellectuals' works to be causal in the ordinary sense. He points out that causal arguments of the type of a chain of multiple events subsequent to one another are rare and dubious.

The world is not made in a way suitable for the isolation of causal chains. Because too many things exercise causal influence on other things, the accounting for an occurence (E) by reference to a causal chain (back to A) will in most cases seem arbitrary and unilluminating. In so far as it is furthermore implied that $\mathrm{E}$ is the product only of $\mathrm{D}$ and $D$ of $C$ (and so on), the account is simply false. 5

Also, causality is extremely difficult to prove and inappropriate for describing groups of artists and scientists.

Communities of this kind do not consist simply of works and workers, but include at least such institutions in which artists or scientists are trained and those by which their works are used in various way.... Anyone who takes the problem of influence seriously has a difficult task to perform. It is hard work to establish a claim to the effect that some feature of a work is the product of an influence of an earlier work having a certain feature. It has to be shown that the author of the later work was indeed familiar with the earlier, that he noted in some appropriate way the relevent feature, that he was not also familiar with some third work possessing some other feature, or at least that his own work was not produced under the influence of such a third work, that he did not come to give to his work the feature that he did independently of any previous works, and probably quite a bit more. 6

Weingartner asserts, rather, that works in intellectual history have an interest and meaning regardless of the problem of causality.

We share with the authors of these essays an interest that is sui generis, one that is satisfied in knowing what the stages were in the development of a complex feature. We are quite content to ignore or take up at another time the 
question of what brought it about. 7

It seems, also, that this interest is similar to the imaginative acts of history-making that collingwood describes. The connection among a variety of musical forms over time or among different conceptions of mechanics, divested on contingent, factual causes, suggests that logical sequence of ideations through time which the historian recreates from his standpoint solidly in the present.

This distinction between causation and a logic appropriate to historical thinking is further elaborated by W. H. Walsh in his essay "The Causation of Ideas." Walsh observes that it is the usual business of historians to take ideas at more than their face value, to "see them not as self-subsistent entities, but as effects which bear witness to their causes and deserve attention just because of that fact." 8 and as with Weingartner, the precise nature of this relationship concerns him. It is not causation in what he calls the Humean sense - as "two items which are separately describable and in which instances of the first sort are found in constant conjunction with instances of the second." 9

But certain other, less precise, relations involving ideas are meaningful. For example, historians often discuss ideas as related to unspoken assumptions, to a climate of ideas. Clearly, this includes the relationship among ideas 
within a common period of time. In this kind of argument, historians demonstrate that

Someone who believed $p$ could not do so unless he also believed $g$, and then show that there is good reason to suppose that he did believe $g$, or took it silently for granted. Fundamentally, what is in question here is logical argument rather than causal reason.... The climate of ideas in which they move certainly affects men's thoughts, but not as an independent causal agent. It is better described as informing their thoughts.... Reference to it is enlightening because it constitutes the standing background of assumptions against which particular ideas were formed.10

Walsh goes on to argue that what intellectual historians might seem to consider causes of ideas outside the sphere of ideas - for example, social, economic, or political forces - are, in fact, not. They are at base relations of thought of the same type as that between an idea and its intellectual climate. Material and social situations do not affect ideas in and of themselves, but are mediated by the thinking individuals' perceptions of these situations; and such perceptions involve options, possibilities. Consequently, "the forming of the idea is not a mechanical effect of the envisaging of a situation, but rather an appropriate response to it."ll

Quentin skinner, in "Meaning and Understanding in the History of Ideas", turns this kind of connection into a thoroughgoing critique of the methods of intellectual historians. For skinner, historical meaning emerges from the diversity among ideas and contexts over time.

It is the very fact that the classic texts are concerned with their own quite alien problems, and not the 
presumption that they are somehow concerned with our own problems as well, which seems to me to give not the lie but the key to the indispensable value of studying the history of ideas. The classic texts, expecially in social, ethical, and political thought, help to reveal - if we let them - not the essential sameness, but rather the essential variety of viable moral assumptions and political commitments. It is in this, moreover, that their essential philosophical, even moral, value can be seen to lie.12

Skinner's essay is a series of cautions against presentism, what he considers an unhistorical, fallacious, banal mode of thinking. These include contamination "by the unconscious application of paradigms whose familiarity to the historian disguises an essential inapplicability to the past"; "sheer anachronism", whereby "a given writer may be 'discovered' to have held a view, on the strength of some chance similarity of terminology, on some subject which he cannot in principle have meant to contribute"; the "mythology of doctrines" mistaking "some scattered or incidental remarks by one of the classic theorists for his 'doctrine' on one of the themes the historian is set to expect"; and the "danger of the historian conceiving his task to be to supply or find in the text a coherence they may seem to lack." "This whole repertoire of Einfluss-studies is based on nothing better than the capacity of the observer to foreshorten the past by filling it with his own reminiscences."13 skinner's alternative view of intellectual history is of a discipline which restricts its meaning to delineating the intentions of textual statements possible within the precise time of their production. 
Skinner's essay has engendered a recent controversy in methodology. For example, Joseph V. Femia, in "An Historicist Critique of 'Revisionist' Methods for studying the History of Ideas", has ascribed to skinner a series of propositions which he considers mostly dubious:

(i) In the sphere of political/social reality, there are no universal truths or perennial questions; all systems of ideas correspond to specific phrases and orders of experience; (ii) past thought must be completely dissolved into its precise context (culture, situation, and so forth); it possesses no capacity for independent life; (iii) the intellectual historian should not concern himself with the validity or present significance of past ideas; texts must not be regarded as vehicles for the exercise of the analyst's own preoccupations; (iv) historicity demands that we focus on what an author consciously intended to say; and ( $v$ ) no subsequent account of a thinker's enterprise could survive the demonstration that it is itself dependent on the use of anachronistic criteria of description and classification - criteria which, in other terms, would have been unintelligible to the thinker himself. 14

Femia suggests that skinner's proposition (i) is something of an historiographical commonplace. The others are a misusing of Husserl. He proposes, in turn:

(a) Ideas may enshrine much that is of permanent value, even though they themselves are untrue or obsolete; b) thinkers do indeed work within intellectual traditions, which - to some extent transcend particular contexts; (c) all history is "contermporary history", dictated by the interests of the historian; study of the past is valuable only insofar as it throws light on present problems or needs; (d) it is neither necessary nor desirable, fram an historicist perspective, to understand a body of thought purely or even primarily in terms of the author's conscious designs. 15

Femia argues that some problems and questions recur in the history of ideas due to the existence of a "permanent substratum of all philosophizing", or human nature.16 In 
addition, "particular authors usually think and write in a way that they regard as relevant to what their predecessors wrote."17 To whatever extent any text is determined by the time and place and social situation of authorship, an ahistorical, individual element is nevertheless present as a residue, transcending contemporary conditions of life. These include ideals and values that are useful in new contexts. Finally, reflection on the act of writing as cognition and creation reveals how this can be so, how texts involve more than intention and context, and why their reconstruction is meaningful.

Although an idea is the product of the thinking which went into it, it also transcends that thinking. There may be logical relations between a person's ideas which do not correspond to any psychological relations between the thought processes which led respectively to those ideas logical relations of which he may be unaware. ${ }^{18}$

Dominick LaCapra, in "Rethinking Intellectual History and Reading Texts", argues a carefully modulated criticism of Skinner, who holds what he terms a documentary view of historical thinking. The documentary includes the facts of the text, its literal assertions; it also refers to the relationship of the text to empirical reality. LaCapra suggests that the writing of the history of ideas is more than this, it is "a subtle interplay between proximity and distance in the historian's relation to the 'object' of study." Texts hold within themselves the totality of history. They are

A situated use of language marked by a tense interaction 
between mutually implicated yet contestatory tendencies. on this view, the very opposition between what is inside and what is outside texts is rendered problematic, and nothing is seen as being purely inside or outside texts. Indeed, the problem then becomes one of rethinking the concepts of "inside" and "outside" in relation to processes of interaction between language and the world.... For the historian, the very reconstruction of a "context" or a "reality" takes place on the basis of "textualized" remainders of the past. 19

In short, the intellectual historian never simply confronts the past, the context and intentions of a great piece of writing, as a pure object, something to be discovered, observed, and reconstructed. Rather, he or she is always engaged with the text, a very part of it, within a process of discourse. Also, interesting texts are resistant to the kind of historical reconstruction skinner advocates by virtue of their uncommonness, "the exceptional way in which they address commonplace themes", in which they "engage in processes that employ or refer to ordinary asssumptions and contest them."20 This applies not only to the ordinary notions of the time within which a text was created, but also the tradition. LaCapra names this conception of texts the work-like. "The work-like supplements empirical reality by adding to, and subtracting from, it." It includes "the roles of commitment, interpretation, and imagination"; and it "engages the reader in re-creative dialogue with the text and the problems it raises." 21 The work-like aspects of the text also engage the historian in attempting

To think further what is at issue in a text or a past "reality", and in the process the questioner is himself questioned by the "other." His own horizon is transformed 
as he confronts still living (but often submerged or silenced) possibilities solicited by an inquiry into the past. 22

LaCapra proceeds to name and describe six different contexts within which a piece of writing is situated. It is the intellectual historian's task both to document and to work at the tensions within these, and their relative importance. The first context LaCapra discusses is "The relation between the author's intentions and the text." He objects that skinner's view of this "tends to assume a proprietary relation between the author and the text as well as a unitary meaning for an utterance." 23 Historical analysis might go beyond this to discuss multiple intentions, contradictions, or ambivalence on the author's part. This comes out of a sense of writing as the process of creating out of experience - which is polymorphous - both latent and surface meanings. Skinner's prescription also ignores the possibility of a community of discourse around the text, the extent to which the author's intention is only one among all those who have commented or reflected upon it. That is, it discounts the aura of the text; it limits the power of readers to respond to a text, enrich it, and create an extended tradition.

Second, is "The relation between the author's life and the text."24 Lacapra warns that this is not merely an analogous relationship, in which aspects of life and writing directly reflect one another; rather, these might "be worked 
or played out differently in each, and these differential relations pose important problems for interpretation." Also, writing is not merely imitation, but also supplementing, an over-abundance. Texts "add something to the ordinary life that as a matter of (perhaps unfortunate) fact might not exist without them." 25

Third, is "The relation of society to texts."26 Again, this is not merely a matter of analogy. It is

That of now precisely the discursive practice, deep structure, or ideology - even the prejudice - is situated in the text other than in terms of instantiation or simple reflection. 27

Those aspects of the text that are conditioned by the specific time of its composition intersect those that are common to a long tradition and those that are special moments of originality. These new moments represent in a complex text the interplay between aspects that are escapist, "imaginary compensation for the defects of material reality", and those that serve "the contestatory function of questioning the empirical in a manner that has broader implications (prescriptions) for the leading of 1ife. 28

Fourth, is "The relation of culture to texts." 29

It is not enough to establish influence or the existence of a shared "paradigm" through the enumeration of common presuppositions, questions, themes, or arguments. One must elucidate in a more precise and detailed way how the borrowed or the conmon actually functions in the texts in question. 30

Fifth, is "The relation of a text to the corpus of a 
writer." 31 Lacapra warns that discontinuities in the body of work of a writer might be intentional, explicit explorations, self-criticisms, or ironies by the writer himself. Finally, is "The relation between modes of discourse and texts." 32 Here, La Capra is concerned with self-referential aspects of a text, those statements which concern the text's own mode of production. These include formal qualities of the writing, as well as restrictions and rules for proper statements. The historian needs to determine how the canons for purity are established, and what contradictions or tensions are excluded or suppressed by such rules.

This concept of the rules of discourse points to a special view of historical thinking, one that is in respects more radically critical than skinner's, that reduces the logical interrelationship of facts and ideas through time to a mere convention, and which has been taken by French structuralists. In a discussion of this tradition, "Structuralism and the writing of Intellectual History", Sande Cohen asserts that historical statements are conventional and hypostatic. Chronology merely

sustains all other levels of historical discourse, including descriptions, assertions, naming of contiguities between facts, elements of sequence and simultaneity, the search for discontinuities between periods. 33

Yet the chronological relationship of events is in itself empty of any concrete meaning. That $B$ followed $A$ in time 
does not explain anything about either $A$ or $B$.

Historians 'touch' the objects of their discourse only by recourse to the already-meant; hence, every shred of historical meaning belongs to the discourse and not to the objects. 34

This hypostasis is related to the function of historical statements as instruments of persuasion, instruction, and domination. Code and convention function to restrict the domain of appropriate statements and enforce particular thoughts, feelings, and values. This view opens up a new range of historical inquiry.

In place of asking "what did that mean?", an historian can ask "how did a past generate a plethora of significations which historians can choose for historical remembrance?" This shift entails that just as one "denaturalizes" historical discourse by trying to write without benefit of conventional meanings, one must "denaturalize" historical objects and model them as past productions of sense which become conventions in historical time and entered into a host of differing intellectual functions. 35

Such rules, constraints, conventions exist as meaningful residues in any system of discourse and in any text. The structuralist prescription for the intellectual historian, then, is to delineate the rules by which a text makes sense and how these came to be used as instruments of domination.

The structuralist tactic for analyzing texts is linguistic specifically, the use of the sentence as a basic model for both texts and non-verbal events. This model suggests two kinds of relations in any system of meaning. In addition to the rules or conventions by which meaningful relationships are constructed, there is the world-view 
within which an audience perceives statements, texts, and events. The first limits the domain of allowable operations, combinations, analogies; the second defines the field of "interpretable meanings and connotations."36 Consequently, the object of analysis is not so much the content, but how the making of sense happens by means of the text. This occurs as a saturation, an interpenetration of form, assumptions, and statements, both within the text and among other texts and events in the social world.

Perhaps the most important figure in this tradition is Roland Barthes. His literary criticism emphasizes historical residues of form that express negation, those aspects of a text that defy commonplace notions, crude conventions of domination, and instead release fantasy and dreams of liberation. For example, in Writing Degree zero, Barthes attempts to describe certain self-conscious aspects of modern literature, which appear only to refer to the writing itself, but which actually reveal writing as an alienated activity, and which thus contain an implicit critique of bourgeois social relations.

It is impossible to write without labelling oneself.... [Literature] must signify something other than its content and its individual form, something which defines its limits and imposes it as Literature, whence a set of signs unrelated to the ideas, the language or the style, and setting out to give definition, within the body of every possible mode of expression, to the utter separateness of a ritual language. This hieratic quality of written signs establishes Literature as an institution and clearly tends to place it above history, for no limits can be set without some idea of permanence. Now it is when History is denied that it is most unmistakably at work; it is therefore 
possible to trace a history of literary expression which is neither that of a particular language, nor that of the various styles, but simply that of the signs of Literature, and we can expect that this purely formal history may manifest, in its far from obscure way, a link with the deeper levels of history. 37

Although the self-referring moments of literature are the most transparent, others - the interstices of structural, general limits to writing - also signify alienation and liberation. Barthes names these limits as language, style, and mode. Language is the compendium of rules and practices which the writers of a particular historical period share. It is the boundary within which written statements must remain in order to make sense.

Suspended between forms either disused or as yet unknown, the writer's language is not so much a fund to be drawn on as an extreme limit; it is the geometrical locus of all that he could not say without, like orpheus looking back, losing the stable meaning of his enterprise and his essential gesture as a social being. 38

style is the personal, idiosyncratic, almost physiological aspect of writing.

[Its] imagery, delivery, vocabulary spring from the body and the past of the writer and gradually become the very reflexes of his art.... Its frame of reference is biological, not historical: it is the writer's "thing", his glory, and his prison, it is his solitude, indifferent to society and transparent to it, a closed personal process, it is in no way the product of a choice or of a reflection on Literature. It is the private portion of the ritual. It rises up from the writer's myth-laden depths and unfolds beyond his area of control. It is the decorative voice of hidden, secret flesh; it works as does Necessity, as if, in this kind of floral growth, style were no more than the outcome of a blind and stubborn metamorphosis starting from a sub-language elaborated where flesh and external reality come together. 39

Mode describes the temporally limited choice a writer makes 
among intentions, ethics, political commitments, naturalness of expression, and other considerations "of the social use which he has chosen for his form".

Thus the choice of, and afterwards the responsibility for, a mode of writing point to the presence of Freedom, but this Freedom has not the same limits at different moments of History. It is not granted to the writer to choose his mode of writing from a kind of non-temporal store of literary forms. It is under the pressure of History and Tradition that the possible modes of writing for a given writer are established; there is a History of writing. But this History is dual: at the very moment when general History proposes - or imposes - new problematics of the literary language, writing still remains full of the recollection of previous usage, for language is never innocent: words have a second-order memory which mysteriously persists in the midst of new meanings. Writing is precisely this compromise between freedom and remembrance, it is this freedom which remembers and is free only in the gesture of choice, but is no langer so within duration. True, I can today select such and such a mode of writing, and in so doing assert my freedom, aspire to the freshness of novelty or to a tradition; but it is impossible to develop it within duration without gradually becoming a prisoner of someone else's words and even my own. A stubborn after-image, which comes from all the previous modes of writing and even from the past of my own, drowns the sound of my present words. Any written trace precipitates, as inside a chemical at first transparent, innocent, and neutral, mere duration gradually reveals in suspension a whole past of increasing density, like a cryptogram.

Writing as Freedom is therefore a mere moment. But this moment is one of the most explicit in History. Since History is always and above all a choice and the limits of this choice. $4 \varnothing$

One mode in Barthes' history of writing is important, here.

This is Marxist writing, wherein the choice of a specialized, technical vocabulary attempts to define an enclosed, totally natural world. This vocabulary has the effect of imposing "a stability in its explanations and a permanence in its method", as well as always expressing a 
consistent set of value-judgements.41 But this closure also binds it to a specific praxis, which is, "in the present state of History", one of domination; and like "any political mode of writing can only uphold a police world." 42 This contradiction points to the basic dilemma of writing in the present era. The potentiality of writing as freedom, as an absolutely good moral choice, is restricted by the present social reality and the structural limits of writing itself.

Within the dynamic of writing as freedom and constraint, certain formal properties of the text, its subversive moments, are especially meaningful. One of these is its fugue-like nature, which Barthes elaborates in his essay "From Work to Text." A meaningful text defies classification. It represents, instead, "a serial movement of disconnections, overlappings, variations", which "coincides with a liberation of symbolic energy."43 That is, elements of the text, whether of form or content, are interwoven in such a unique way, they throw the reader into a special state of confusion, back upon his or her own psychic resources. It requires the reader to enter into the actual construction of the text. So it is, on a deep and cooperative basis, an empowering of the reader.

This means that the Text requires that one try to abolish (or at the very least to diminish) the distance between writing and reading, in no way by intensifying the projection of the reader into the work, but by joining them in a single signifying practice. ${ }^{44}$ 
In The Pleasure of the Text, Barthes further elaborates this psychology of reading - not as cognition, but as erotic liberation. This is achieved by what he terms the redistribution of language.

Such redistribution is always achieved by cutting. Two edges are created: an obedient, conformist, plagiarizing edge (the language is to be copied in its canonical state, as it has been established by schooling, good usage, literature, culture), and another edge, mobile, blank ready to assume any contours), which is never anything but the site of its effect: the place where the death of language is glimpsed. These two edges, the compromise they bring about, are necessary. Neither culture nor its destruction is erotic; it is the seam between them, the fault, the flow, which becames so. 45

Characteristics of this cutting edge of the text include shocks, excesses, disturbances, the loss which is proper to ecstacy, the split that is an overcoming of "the moral unity that society demands of every human product", extravagant originality or repetition, uncompleted statements which avoid being ideological by leaving the reader hanging, a "subtle subversion, what is not directly concerned with destruction, evades the paradigm, and seeks some other term: a third term, which is not, however, a synthesizing term, but an extraordinary term", an interrelatedness, by which "reading and the risks of life are subject to the same anamnesis."46 This is a psychoanalytic typology, "linking the reading neurosis to the hallucinated form of the text." 47 It is the encountering of the reader's individuality within the affects, frictions, and open spaces of the text. 
In this regard, I want to note also I. A. Richards' Practical criticism, a pioneering work in the problem of the relationship between a text and the variety of individual readings it might elicit. Richards' concern is primarily with developing a criteria for judging poetry. He approaches this by defining a typology of failures of intelligence and sensibility possible in a critical reading.

The root question is whether responses reflect the poem itself, or some private poem prompted by the material set before the reader and by his own reminiscences. 48

What are significant, here, are the categories of this typology, which, in a digression, Richards applies to any text, and particularly to texts of scientific discourse, such as Character Analysis.

It is plain that most human utterances and nearly all articulate speech can be profitably regarded from four points of view. Four aspects can be easily distinguished. Let us call them Sense, Feeling, Tone, and Intention....

If we survey our uses of language as a whole, it is clear that, at times, now one now another of the functions may become predominant. It will make the possible situations clearer if we briefly review certain typical forms of composition. A man writing a scientific treatise, for example, will put the sense of what he has to say first, he will subordinate his feelings about his subject or about other views upon it and be careful not to let them interfere to distort his argument or to suggest bias. His tone will be settled for him by academic convention; he will, if he is wise, indicate respect for his readers and a moderate anxiety to be understood accurately and to win acceptance for his remarks. It will be well if his intention, as it shows itself in the work, be on the whole confined to the clearest and most adequate statement of what he has to say. But, if the circumstances warrant it, further relevant aims - an intention to reorientate opinion, to direct attention to new aspects, or to encourage or discourage certain methods of work or ways of approach - are absolutely fitting.... 
Consider now a writer engaged upon popularizing some of the results and hypotheses of science. The principles governing his language are not nearly so simple, for the furtherance of his intention will properly and inevitably interfere with the other functions.

In the first place, precise and adequate statement of the sense may have to be sacrificed to some degree, in the interests of general intelligibility. Simplifications and distortions may be necessary if the reader is to "follow." Secondly, a much more lively exhibition of feelings on the part of the author towards his subject-matter is usually appropriate and desirable, in order to awaken and encourage the reader's interest. Thirdly, more variation between the expert and his lay audience must be created, and the task, as many specialists have discovered, is not easy. These other functions will interfere still more with strict accuracy of statement; and if the subject has a "tendency", if political, ethical, or theological implications are at all prominent, the intention of the work will have further opportunities to intervene. 49

A correct reading - or meaning - happens by an analysis of how these characteristics are patterned throughout the text. Such an analysis is valuable to the extent it is integrated, reflecting an individual authenticity of experience. This is especially a problem with the category of feeling.

If we compare our powers of analyzing sense and feeling we shall recognize at once that feeling, in contrast with sense, is a will-o'-the-wisp. We have a marvelous apparatus of inter-engaging and overlapping symbols for handling and elucidating sense, a logical machine of great sensitiveness and power, equipped with automatic safety devices and danger signals in the form of contradictions. Logical language has even reached such a high state of development that it can now be used to improve and extend itself, and may in time be made self-running and even foolproof. For handling feeling we have nothing at all comparable. We have to rely upon introspection, a few clumsy descriptive names for emotions, some scores of aesthetic adjectives and the indirect resources of poetry, resources at the disposal of a few men only, and for them only in exceptional hours. Introspection has become a byword, even where intellectual and sensory products and processes are concerned, but it is even more untrustworthy when applied to feelings. For a feeling even more than an 
idea or image tends to vanish as we turn our introspective attention upon it. We have to catch it by the tip of its tail as it decamps. Furthermore, even when we are partially successful in catching it, we do not yet know how to analyse it. Analysis is a matter of separating out its attributes, and no one knows yet what attributes a feeling may have, what their system of interconnections is, or which are important, which trivial.50

An attempt at such an analysis of feeling has been made by the American literary critic Norman H. Holland, using the insights of depth psychology. For Holland, meaning emerges from the transformation of unconscious drives into conscious affects. This is a function of form. Writing and reading typically release erotic fantasies and guilt anxieties, as they simultaneously displace these to language and understanding, as defensive reactions.

Our conscious attention shifts from the content of the utterance (which is presumably sensual, and containing deep erotic associations, indeed well-spring) to its form. Attention, concern if you will, psychic energy, are taken away from substance and given to language.... such a displacement weakens our involvement with the deeper, fantasy levels, fraught with fear and desire; instead, we concentrate our involvement on the verbal level. 51

The affective meaning of a text is a fugue, a movement along the range of discontinuities defined by fantasy content and literary form.

I have gone into these notions of Barthes, Holland, and Richards about the nature of literary response to an extent perhaps inappropriate for understanding character Analysis, a text of scientific prose. But in the course of discussing Character Analysis, a similar concept of the patterning of explicit, conscious, yet powerfully evocative 
statements about sexual orgasm and repressed drives with an unusually wide variety of formal strategies, of distributions of language, for an expository text will hopefully help situate Reich's work within a general history of human liberation.

I also want to note Hayden White's view of the status of historical statements. He asserts that history is made entirely of free creative choices; it is iconic narrative, or poetry; and its meaning is wholly contained within its mode of representation. White suggests a typology of form for history, by which a contextual methodology, which this essay will attempt to follow, implies a liberal ideology and an ironic world-view - self-critical and ethically relativist. By this strategy, relationships between contexts are diverse and explainable functionally. So Character Analysis, in its conviction, its contradictions, its patterning of language, will be understood as providing a technique for hope, redress, and critique of the dominant social system. It will be explained as justification for certain decisions Reich made in his personal life, and as an instrument in his own psychic adjustment to reality. Generally, why events occurred

Is to be explained by the revelation of the specific relationships they bore to other events occurring in their circumstantial historical space.... In this operation the aim of explanation is to identify the "threads" that link the individual or institution [or work] under study to its specious sociocultural "present." 52 
It seems it is possible to hold an ironic viewpoint with rigor and critical self-consciousness, while questioning white's sense of an historical time as a purely imagined, specious object. Social processes might be real informants of a text. The world is certainly composed of made objects - artifacts, institutions, and human relationships. Over time, men and women act cooperatively and, it would seem, both consciously and unconsciously - to change these. The production of a text belongs to the same historical process. It bears the marks not only of its individual creation and its general type, but also the special features of its time, the particular face presented by particular aggregates of men's and women's thought and activity. These represent autonomous choices. But they are also definable by their temporal unity. Character Analysis represents a singular act of writing: it is also classifiable as a narrative, a polemic, and a scientific argument. It is especially a chosen position - a critique of capitalism, politics, and sexual morality, but engaged with its own time. As such, it shares a particular social milieu and climate of opinion about reason, the human body, and freedom. Certainly, this is the view of historical meaning Reich himself expresses in Character Analysis.

In his position as the object of his needs, however, man is also and at the same time the subject of history and of the social process of which he "himself is the author", not, to be sure, exactly as he would like to be, but under definite economic and cultural presuppositions, which determine the content and outcome of human action. 53 
All these features of Character Analysis meet in the formal qualities of the text - along the erotic edges of writing which Reich creates out of the aspirations, limits, and contradictions of his life and his age. And again, these consistently signify liberation. In short, I am using varied methodologies as tools for delineating a particular pattern by which Reich espouses freedom throughout Character Analysis. Following Richards and Holland, I am attempting to connect formal peculiarities of the text to my personal, emotional, even idiosyneratic responses in order to elicit an authentic, convincing reading. After Barthes, I am attempting to describe how certain of these literary characteristics might be historical evidence of the basic liberating value of Reich's writing. My use of Barthes is crucial. Whatever inconsistencies of authoritarian attitudes appear in Reich's text, my position is that these are overcome in the formal, liberating qualities of the work. Following Walsh, Femia, and LaCapra, I hope to suggest how events in Reich's life, his cultural and social milieu, and his generation might have informed these contradictions and liberating aspects. Following Weingartner, I want to suggest that Character Analysis contains certain similarities and differences compared with a number of other texts. These other texts also examine the relationship between sexuality and political domination. 
They help place Reich's work within a discourse, within the context of the historical development of a theory of liberation. After Collingwood, I want to believe I am creating an image of the past validated by its continuity with the present - with an objective rationality which endures through time. And like Reich at his best, I see this rationality as the hope and strategy for freedom and tolerance. 
CHAPTER II

ENDNOTES

1. R. G. Collingwood, The Idea of History (Oxford, $1946)$, p. 110 .

2. Ibid., p. 155.

3. Ibid., p. 218 .

4. Rudolph H. Weingartner, "Some Philosophic Comments on Cultural History", History and Theory 7 (1968), p. 39.

5. Ibid., p. 49.

6. Ibid., pp. 53-54.

7. Ibid., pp. 54-55.

8. W. H. Walsh, "The Causation of Ideas", History and Theory 14 (1975), p. 187.

9. Ibid., p. 190.

10. Ibid., p. 19ø-191.

11. Ibid., p. 193.

12. Quentin Skinner, "Meaning and Understanding in the History of Ideas", History and Theory 8 (1969), p. 52.

13. Ibid., pp. 7, 8, 12, 16, 27.

14. Joseph V. Femia, "An Historicist Critique of 'Revisionist' Methods for Studying the History of Ideas". History and Theory 20 (1981), pp. 114-115.

15. Ibid., p. 115.

16. Ibid., p. 123.

17. Ibid., p. 124 .

18. Ibid., p. 131. 
19. Dominick Lacapra, "Rethinking Intellectual History and Reading Texts", History and Theory 19 (1980), p. 247.

20. Ibid., p. 249.

21. Ibid., p. 250 .

22. Ibid., p. 251.

23. Ibid., p. 254 .

24. Ibid., p. 256.

25. Ibid., p. 257.

26. Ibid., p. 258.

27. Ibid., p. 259.

28. Ibid., p. 261.

29 . Ibid., p. 263.

30. Ibid., p. 265.

31. Ibid., p. 268.

32. Ibid., p. 269.

33. Sande Cohen "Structuralism and the writing of Intellectual History", History and Theory 17 (1978), p. 179.

34. Ibid.

35. Ibid., p. 181 .

36. Ibid., p. 183.

37. Roland Barthes, Writing Degree zero and Elements of Semiology, translated by Annette Lavers and Colin Smith (Boston, 1970), pp. 1-2.

38. Ibid., p. 10 .

39. Ibid., pp. 10-11.

40. Ibid., pp. 15-17.

41. Ibid., p. 23.

42. Ibid., p. 28 . 
43. Roland Barthes, "From Work to Text", in Image, Music, Text, translated by Stephen Heath (New York, 1977), p. 158.

44. Ibid., p. 162.

45. Roland Barthes, The pleasure of the Text, translated by Richard Miller (New York, 1975), pp. 6-7.

46. Ibid., pp. $31,35,39$.

47. Ibid., p. 63 .

48. I. A. Richards, practical Criticism: A Study of Literary Judgement (New York, 1929), p. 95.

49. Ibid., pp. 175-178.

50. Ibid., p. 207.

51. Norman H. Holland, The Dynamics of Literary Response (New York, 1968), 135.

52. Hayden v. White, Metahistory: The Historical Imagination in Nineteenth Century Europe (BaItimore, 1973), p. 18 .

53. Wilhelm Reich, Character Analysis, translated by vincent R. Carfagno (New York, 1972), p. xxiii. 
CHAPTER III

BIOGRAPHY AND TEXT

Perhaps the most disconcerting intersection between Character Analysis and its various contexts is where Reich's sympathy for his patients in the book seems to emerge from his own emotional struggles.l Throughout his life, Reich was himself a person in trouble. So character Analysis represents a radical interpenetration of life and text, by which the author's personal experience becomes a special kind of evidence for his argument. Events in Reich's life also have their formal correllative in the text. This is the pattern of self-references in Character Analysis which indicate both the self-justifying anger of a lonely man and his basic life-long impulse toward liberation. Consequently, I am going to describe Reich's book first and foremost in relationship to the story of his life.

Wilhelm Reich was born on March 24, 1897, in Galicia, and grew up in the Austrian Ukraine. His father Leon was a free-thinking Jewish businessman and farmer, raising beef cattle under contract to the German army on his large estate. He was proud, short-tempered, jealous, and brutal to his family and his workers.

Socially, the long arm of [his] father was often felt. Reich was not allowed to play with peasant children nor 
with Yiddish-speaking Jewish children. The father appears to have been socially very ambitious, consorting with government officials and other high-level persons, but Willy's opportunities for playing with peers were scarce. The feudal quality of the life is further revealed by a story Reich told his second wife, Elsa Lindberg. As a child he was not permitted to take part in village dances. But one night, while he was watching the dance, a peasant boy threw a stone at him. Willy told his father and Leon hit the boy's father. So, quite early, Reich was exposed to the brute power not only of the father in the home but of the property owner in the community, and he experienced both in ways that would mark him. ${ }^{2}$

During his childhood, Reich resisted this difficult man; and, according to his third wife, Ilsa ollendorff, resentments continued throughout his life.

Reich talked very little about his relationship with his father. I have the feeling that it was a very ambivalent relationship, because on more than one occasion Reich tried to imply that he was not really his father's son, that maybe his mother had a relationship with one of the Ukrainian peasants - a rather unlikely story for that time and place - and in the end, went so far as to offer the even more unlikely proposition that he was the offspring of his mother and a man from outer space. 3

But he also held onto positive memories of his father.

Reich took great satisfaction in the fact that his father was not religious, aside from some ritual Jewish observances to appease more orthodox relatives; that Leon was cosmopolitan in orientation and modern-minded in his farming practices; that he was a working property owner, not a "parasite." In later years Reich stressed that his mother, too, was very active on the family estate, a leader who helped organize the women's work on the farm just as the father directed the men. 4

His mother Cecilia was a very beautiful woman, a good housewife, unintellectual according to family tradition, and deeply loved by her son.

All through his life Reich idolized his mother. No other woman's cooking over the years, for example, could ever reach her perfection. Elsa Lindenberg, Reich's second wife, told me that she was never able to make an apple 
strudel just like his mother used to make, and no matter how hard I tried I could never produce a special cabbage dish that he liked exactly the way his mother had made it. I once came close when I slightly burned the cabbage, and ever since I have had my private doubts about Mrs. Reich's perfection as a cook. 5

However contradictory Reich's deep feelings for his parents were, the eccentric charm of these anecdotes of burnt cabbage and lovers from outer space imparts a soft light on his childhood. It was in many respects idyllic.

Reich often spoke with a certain nostalgia of his childhood years on the farm. He remembered especially the young Ukrainian girls who were his nursemaids, their earthiness, and the warmth with which they cuddled him. He remembered the folk songs they used to sing, and the folk dances in which he sometimes participated. He told of the large fishponds where carp were raised, and although he liked to eat freshly caught freshwater fish, he never liked fishing, and thought of it as a cruel sport. He used to say that it always made him think of a great big giant dangling a juicy steak in front of a human, only to hook the poor human on a sharp barb the moment he was tempted to take a bite. He remembered riding for hours over the fields, surveying the harvest, and enjoying the smell of the fields, and the newmown hay. 6

This idyll did not lack a sexual dimension.

He remembered as a boy of four sleeping in the servants' room when his parents were away. On several occasions, he overheard or witnessed intercourse between a maid and her boyfriend. In the course of these experiences, he asked the maid if he could "play" the lover. He stressed to one informant that she permitted him to do so in a very helpful way. Without stimulating him actively, she allowed him to move on top of her. Whether this happened once or often is uncertain. But Reich clearly attributed great importance to his relationship with this peasant girl. He once said that by the time he was four there were no secrets for him about sex, and he related this clarity in part to his sexual play with his nursemaid. 7

An equally significant place in his memories was held by a remarkable tutor, as Reich disclosed in a third-person voice 
autobiographical narrative he published in 1948.

WR's interest in biology and natural science was created early in his life on the farm, close to agriculture, cattle-breeding, etc., in which he took part every summer and during the harvest. Between his eighth and twelfth years, he had his own collection and breeding laboratory of butterflies, insects, plants, etc. under the guidance of a private teacher. The natural life functions, including the sexual function, were familiar to him as far back as he can remember. That may very well have determined his later strong inclination, as a biopsychiatrist, toward the biological foundation of the emotional life of man, and also his biophysical discoveries in the fields of medicine and biology, as well as education. 8

These anecdotes also mask a complex of tragedies, a core of events, "an existential debt all the rest of a lifetime." 9 Their fanciful aspects are more than the quaint and hazy memories of childhood; they are a meaningful breakdown of words and remembrance. Reich's mother committed suicide when he was fourteen, after he had revealed to his father her real love affair with this tutor. Reich published and even more complicatedly voiced narrative of the affair as a case study in his first clinical article, "The Breakthrough of the Incest Taboo in Puberty", in 1920. The tale is told within a purported letter by a patient to Reich; in reality, the patient is an imagined persona for Reich, himself. This patterning of imagination and clinical evidence, self and vocation, has a meaningful decorum.

N (name of tutor) began to court her, stimulated by walks they took together. He apparently became ever bolder as he recognized how things were going - the jealous scenes, etc. between my parents, and the fact that mother liked him. At the beginning I was not completely clear about the developing relationship. But I began to follow them when I noticed mother going into his room when father napped after lunch. In part I was erotically curious, in part I was 
filled with fearful thoughts that father would wake up. And from then on I played spy and pursuer, but at the same time also defender (italicized by me - the analyst) against any surprises from father. I cannot clarify further the reasons for $\mathrm{my}$ behavior. Either it was unconscious hatred against my father or sexual titillation to be aware of such stunning secrets about which my father remained ignorant. I believe that both factors were equally responsible for my behavior.

The relationship between $m y$ mother and tutor grew ever deeper; not a day passed in which they did not seek and find the opportunity to be alone....

Shortly after Christmas father went away for three weeks and I experienced the most horrible, the most upsetting events, which burned themselves deeply into my feelings and thoughts.

Mother slept, as always during father's absence, in the last bedroom on the corridor. After that came our room, then the dining room, and then his ( $\left.N^{\prime} s\right)$ room. Right on the first night ( $I$ was so tense I had not closed my eyes) I heard my mother get up and - the horror grabs me by the throat! - heard her slippered walk and saw her, clad only in a night gown, pass through our room. Soon I heard the door of his room open and not completely shut. And then quiet.

I sprang up from my bed and followed, shivering, my teeth chattering from anxiety, horror, and cold; I moved right up to the door, which was only partly closed, and listened. Oh horrible memory, which tears my remembrance of my mother to dust, her memory always besmirched anew with dirt and muck! Must I then say everything? The pen bristles, no, my ego, my whole being is against it, and yet I will and must write on.

I heard kisses, whispers, the frightening noise of the bed, and on it lay my mother. And a few yards away stood your son and heard your shame. Suddenly quiet. I had evidently made a noise in my excitement, for I heard calming words from him and then, then again, ohl (The last sentence, especially the last words, written apparently in the highest excitement, with heavy strokes of the pen.)

only quiet, quiet toward this nerve-shattering tragedy, in order to accomplish the superhuman! To judge objectively! What a mockery! What a resolution!

From that catastrophic night I remember only that my wish at first was to plunge into the room but I was held back by the thought: they will kill you!

I had read somewhere that lovers get rid of any intruder, so with wild fantasies in my brain I slipped back to my bed, my joy of life shattered, torn apart in my inmost being for my whole life!

So it went, night after night; always I slipped back and waited till morning. Gradually I became used to it! 
The horror disappeared and erotic feelings won the upper hand. And then the thought came to me to plunge into the room, and to have intercourse with my mother with the threat that if she didn't I would tell my father. For my part, I went regularly to the chambermaid.10

It was not uncommon for Freud and his followers to fictionalize their case histories to some extent and to project their personal memories into them. And the origins of this letter must remain obscure. It might be largely authentic, perhaps a document from Reich's own, abortive analysis under Isidor Sadger. or it might be primarily a literary object, perhaps an imitation of the romantic epistolary novel. In either case, it contains a series of significant edges, disjunctures, displacements to language.

The general movement of the piece is indicated in the second sentence, one of increasing boldness and selfrecognition toward fulfillment in the boy's fantasies and his mother's betrayal of the core oedipal situation. Ambiguity is introduced by a self-referring break in the narrative's movement, the parenthetical aside "(italicized by me - the analyst)", that is both a confusion of persona and a suspension of affect by transferring the reader's attention to a formal matter. As the sexual drama intensifies, a number of rhetorical flourishes intervene, which in their literariness do not so much express feeling as fend off the imminent erotic climax.

0 horrible menory, which tears my remenbrance of my mother to dust, her memory always besmirched anew with dirt and muck! Must I then say everything? The pen bristles, no my ego, my whole being is against it, and yet I will and must 
write on.

The excesses, here, the repetitions of the word memory and of the allusions to filth, as well as the formal emphasis on hesitation in the stop and go diction, are parried by another matter of fact intervention by the analyst persona.

(The last sentence, especially the last words, written apparently in the highest excitement, with heavy strokes of the pen.)

The most significant formal residue is the affectless tone of the final statement, "For my part, I went regularly to the chambermaid." Reich's patient persona abruptly assumes the matter-of-fact attitude of the analyst. Not only does this sentence seem to be an after-thought, an anti-climax that is being tossed aside; it also signifies a complex historical attitude. By one reading, it might suggest domination, the objectification of the servant as a mere recourse, an instead-of, a useful receptacle for Reich's blocked passion for his mother, but of no consequence in and of herself. Formally, the sentence resembles the reified discourse of instrumental science. But this radical change of tone creates a more complex edge. The simplicity of the statement, reflecting the diction of the analyst, also suggests a turn to reason, even cleanliness, a purification, after the emotional and rhetorical excesses of the oedipal fantasy •

of course, it also represents a diversion from a very real, unrelenting tragedy. Cecilia's suicide was a drawn 
out and horrible one. Unable to envision divorce or flight, she endured her husband's recriminations and increased brutality for two years, until in 1909 she drank a household solvent, died after several days of great pain, left Reich's father devastated. Father and son became very close, perhaps by virtue of their shared remorse, but only for a brief time.

Only the thought of his two sons kept him from taking his own life. He insured his life heavily and afterward contracted pneumonia, standing for hours in cold weather in a pond, ostensibly fishing. The pneumonia developed into tuberculosis and he died in 1914.11

The insurance for his sons was never recovered, as the company suspected suicide. In the end, Reich's younger brother Robert assumed financial responsibility for the two impoverished young men during Wilhelm's student years; and the strain very likely, or at least so Reich felt, precipitated his death by tuberculosis in 1926.

A two-sided meaning emerges from this incredible family tragedy and the contradictions in Reich's memories of it, and finds its way into character Analysis. First, sexual activity, the tender female embrace, remains with Reich both the final recourse of life and an absolute justification for forgiveness. And second, words are a much more problematic form of human expression. They are elusive; they have the power to mask the truth, unleash suffering, and bind remorse. These two assumptions form the foundation of Reich's psychoanalytic theory. His career was 
to move psychoanalytic technique beyond words into physical processes. They reflect a combination of powerful experiences - of sensuous peasant girls, a beloved mother, a hard father, a young boy's confused attempt at truthful utterances and good faith, and their tragic consequences.

These events gave to Reich's psychoanalytic career a powerful impetus. After his discharge from the Austrian army in 1918, Reich entered the University of Vienna as a law student; but he switched to medicine before the end of his first semester. With otto Fenichel, Reich organized an extracurricular seminar on sexuality. This led to studying psychoanalytic writings and an introduction to Freud in 1919. By early 1920, Reich was seeing patients Freud had referred to him, and in the summer he became a guest member of the Vienna Psychoanalytic Society, at the remarkable age of twenty-three.

Finishing medical school in 1922, he became the first clinical assistant at the Psychoanalytic polyclinic in Vienna, which Freud had established to provide therapy to working class people, laborers, farmers, clerks, and students. Reich observed in these patients a different form of emotional disorder than freud had treated in his middle class clients. Instead of typical symptom neuroses, such as obsessive-compulsive habits or hysterical paralysis, Reich found generally disorganized lives and anti-social and selfdestructive tendencies. Also in 1922, Reich suggested and 
Freud supported the establishment of the Technical Seminar for Psychoanalytic Therapy. Failures young analysts encountered in their practices were discussed under the leadership of an experienced therapist. Reich assumed this position in 1924 and held it into 1930. Reich's theoretical innovations, his development of psychoanalysis beyond symptom analysis to the systematic treatment of the entire character as a biological entity, came out of his experiences in the Polyclinic and the Technical seminar.

Reich dealt with the failures young analysts were coming across in their individual practices under the problem of resistance. In Freud's work, the concept of resistance explains the impediments to free verbal associations - basically as the fear of touching upon repressed memories. Overcoming resistance is a crucial point in classical psychoanalytic theory.

If we communicate to a patient some idea which he has at one time repressed but which we have discovered in him, our telling him makes at first no change in his mental condition. Above all, it does not remove the repression nor undo its effects, as might perhaps be expected from the fact that the previously unconscious idea has now become conscious. on the contrary, all that we shall achieve at first will be a fresh rejection of the repressed idea.... Actually there is no lifting of the repression until the conscious idea, after the resistances have been overcome, has entered into connection with the unconscious memorytrace. It is only through the making conscious of the latter itself that success is achieved. 12

That is, the patient must not only know and understand his burdensome memories, he must re-experience them as recollection and the consequent release of cathectic energy. 
Reich extended the concept to include the production of too much material with no emotion. Patients tended to offer deceptions and trivialities in order to please the analyst out of politeness, while defending themselves against the pain and deep feelings that are consequences of cure. Even authentic verbal material was often merely translated into new symptoms and deeper levels of the disturbance. In classical theory, resistance is overcome by transference, the emergence of the analyst as a new object-cathexis, to reactivate erotic strivings, overcome repression, and make conscious their association with the past. Reich essentially broke with Freud in arguing that the affect produced by remembering repressed material was insufficient to bring about cure. Transference and remembrance in the analytic situation, he argued, was secondary to establishing a permanent object-cathexis - a fulfilled romantic relationship in the patient's daily life.

For Reich observed that his patients' patterns of sexual activity, both past and present, were more consistently related to the success or failure of their analysis than any pattern of words.

We learn from analytic practice that some cases, notwithstanding protracted and copious analysis, remain refractory; whereas other cases, despite incomplete examination of the unconscious, can achieve lasting practical recovery. In comparing these two groups, it turned out that, after the analysis, the former cases, namely those which remained refractory or readily relapsed, had not succeeded in establishing a regulated sexual life. In an investigation of the prognosis of average cases, it was further shown that, under otherwise equal conditions, 
the chances of cure were that much more favorable the more completely genital primacy had been achieved in childhood and adolescence. 13

Reich developed a therapeutic procedure that attacked directly his patients' physical bearing, strained mannerisms, and polite lies into which their natural sexual expressiveness had been channelled and suppressed. He sensed that the neurotic's apparent niceness concealed attitudes of doubt and distrust toward her or himself, the analyst, and life in general. He raised this contradiction by forcing their anger and ultimately encouraging the integration of their passion into genitality. He abandoned, here, Freud's principle of strict neutrality toward his patients. Instead, he criticized and mocked them - going so far as to manipulate them physically, to attack the knotting and atrophying of their musculature, their physiological defenses against erotic sensations. He treated their character armor, a concept by which he described a functional, integrated distortion - a physical crippling, an attitude, and an entire mode of existence.

In the analysis, the neurotic character traits as a whole prove to be a compact defense mechanism against our therapeutic efforts, and when we trace the origin of this character "armor" analytically, we see that it also has a definite economic function. Such armor serves on the one hand as a defense against external stimuli; on the other hand it proves to be a means of gaining mastery over the libido, which is continuously pushing forward from the id, because libidinal and sadistic energy is used up in the neurotic reaction formations, compensations, etc. Anxiety is continually being bound in the processes which are at the bottom of the formation and preservation of this armor in the same way that, according to Freud's description, anxiety is bound in the compulsive symptoms. 14 
The character armor represents a systematic typology, relating specific emotional disorders, character types, and regions of the body where blocked erotic energy accumulates. The treatment of the armoring allowed not only psychic liberation, but also the freeing of the body for sexual potency. Reich discovered that after the resistances had been addressed, after the character and its physical armoring had been attacked and dissolved, the important childhood memories, the Oedipus complex and castration fear, came forth more easily and were faced honestly by his patients. In addition, they experienced symptoms as emanating from outside, like germs or social pressures, rather than as part of their selves. They became able to deal with the blows of the world with courage and to distinguish the erotic strivings inside their bodies with hope for fulfillment.

The basis of this physiology of emotions is the radical valuing of silence.

Orgone therapy, as opposed to all other forms of therapy, attempts to influence the organism not through the use of human language but by getting the patient to express himself biologically. This approach leads him into a depth which he continually flees. In this way the orgone therapist learns, understands, and influences the language of the living organism. It is hardly possible to obtain the primary language of expression of the living protoplasm in the patient in a "pure" form. If the patient's mode of expression were biologically "pure", he would have no reason to seek the help of an orgone therapist. We have to go through a welter of pathological, unnatural expressive movements (i.e., movenents not native to the process of the living organism) to arrive at the genuine biological mode of expression. Human biopathy, indeed, is nothing other 
than the sum total of all the distortions of the natural modes of expression of the living organism. By unmasking the pathological modes of expression, we get to know human biopathy at a depth inaccessible to methods of cure operating with human language. This is not to be ascribed to a deficiency on the part of these methods; they are adequate in their own spere. With its distorted expression of life, however, biopathy lies outside the sphere of language and ideas. 15

Reich is asserting in Character Analysis that every human attitude, gesture, and utterance are the functional expression of a physiological process. This process is the flow of sexual energy. It occurs beyond words and conscious intentions. Indeed, it is generally twisted within its mediations - the experiences of social life, learned perversions, deceptions, and restraints. It is transformed within layers of words and memories into anxiety, neurosis, and disease. It is authentic only as the silent, autonomous release of orgasm which is the convulsive expression of the core of the human body, silent and imageless. Reich views this as a significant departure from psychoanalysis.

The orgasm is not a psychic phencmenon. On the contrary, it is a phenomenon brought about solely by the reduction of all psychic activity to the primal vegetative function, i.e., precisely by the suspensian of psychic fantasizing and imaginative activity. It is nonetheless the central problem of psychic economy. Its inclusion in psychology not only permits a concrete treatment of the quantitative factor in psychic life and the establishment of the connection between the psychic and the physiological factor (i.e., vegetative factor). Over and above this, it leads of necessity to a significant change in the psychoanalytic view of the neurotic process. Formerly, the Dedipus complex was regarded as an explanation of neurotic illness. Today we realize that whether or not the oedipus complex leads to neurosis depends upon other factors: the childparent conflict does not become pathogenic unless there is also a disturbance in the child's sexual economy; this early disturbance lays the groundwork for the subsequent 
malfunctioning of the libido economy in adulthood; it derives its energy precisely from what helped to bring it about, i.e., the stasis of genital-sexual energy. In this way the accent was shifted from the content of the experience to the economy of vegetative energy. 16

Certainly, Reich, who intends to convey in writing both a radical departure from accepted theory and a reality which resides in silence, faces serious formal difficulties, both of persuasion and conceptualization. I want to juxtapose, here, a passage from each of the two major case studies in Character Analysis. These represent solutions to the writer's problem; they illustrate what tends to happen in reading this text - the experience of a variety of shocks and disjunctures, empty spaces, which allow themselves to be filled with the reader's feelings and selfconsciousness. First, is of a masochistic character type.

The patient, whose analysis we will follow in its essential features, without going into the full details of his illness, began the treatment with the following complaints: he had been wholly incapable of work and socially apathetic since he was sixteen. In the sexual sphere, there was a severe masochistic perversion. He had never cared for intercourse with girls but had masturbated nightly for hours in the way characteristic of the pregenital libido structure. He would roll around on his stomach, and squeeze his penis while fantasizing that a man or woman was beating him with a whip. In short, he did not masturbate in the normal way, i.e., exciting the penis by regular friction, but by kneading it, clamping it between his thighs, rubbing it between the palms of his hands, etc. When he sensed that he was about to ejaculate, he would hold back and wait until the excitation had subsided, in order, then, to begin anew. He masturbated in this way night after night, often during the daytime also, until finally, completely exhausted, he would yield to an ejaculation in which the semen did not spurt out rhythmically but merely flowed out. Afterwards, he felt battered, extremely tired, incapable of doing anything, fretful, "masochistic", tormented. He had an especially hard time dragging himself out of bed in the morning. In 
spite of an overwhelming sense of guilt, he was not able to put a stop to this "loafing in bed." He later described the whole thing as "masochistic bog." The more he rebelled against it, the less he succeeded in extricating himself from this "masochistic mood", the more deeply he was engulfed by it. When he entered analysis, this kind of sexual experience had been going on for years. The effects on his personality and on his emotional life had been devastating. 17

What is noteworthy in this passage is the candor and concreteness with which the perversion is described. The straightforward erotic material is broken up only once, by the brief shift to classical clinical language, a reference to "the pregenital libido structure." The writing is managed, instead, by the formal creation of suspensions. The first of these is the italicized print of the statement:

When he sensed that he was about to ejaculate, he would hold back and wait until the excitation had subsided, in order, then, to begin anew.

This is a break in the material face of the text; it is also a formal reference to the content of the statement, to the breaking up of the flow of conscious erotic material. As such, it throws the reader into self-consciousness; it creates a gap in the flow of words for contemplation or the intrusion of personal associations. A second formal curiosity also serves this function. This is the series of enquoted words: "masochistic", "loafing in bed", "masochistic bog", and "masochistic mood." Not until the third and fourth item is the referent of the quotations indicated. This creates a similar space of questioning, 
confusion, opening for self-consciousness in the course of reading. In addition, the erotic content of the narrative tends to overpower the one attempt Reich makes to establish a conventional control over his material. This is the remark, "he did not masturbate in the normal way." In the context of sexology in the 1930"s, it is itself provocative and liberating - that masturbation should at all be judged normal. These offer considerable space or freedom for the reader to work at her or his own relationship to the very frank material Reich presents - in a sense, to self-create the text and open up the psychoanalytic discourse as potentiality.

A somewhat different formal strategy appears in Reich's narrative of the case history of a schizophrenic, but it signifies a similar moment of cooperation between author and reader.

What is to follow now will appear utterly incredible. Therefore, I wish to assure the reader that I had not the faintest idea of the existence of such mechanisms. But since the treatment of this case the facts to be described have been found in several other cases of schizophrenia. Clinically, as well as orgone-biophysically, there can no longer be any doubt about the reality of these facts.

Nineteenth session

The patient came to the nineteenth session very calm and co-ordinated, but slightly absent-minded. She spoke very slowly, as if against some great obstacle; she said that she was very depressed. She had been shopping the day before, for the first time in many months; she had bought many things, had enjoyed them as never before, had shown them to her friends, and had slept well. The following morning, however, she was overcome by great emptiness and tiredness. There was a "nothingness" in her; and she had felt the need to sit quietly in same corner "and not to move at all." "Every movement was such a great effort." She wanted to be by herself. She gave the impression of an 
oncoming catatonia with imobility and perseveration.

"Everything was very far away.... I watched myself as if I were outside of myself; I felt clearly double; a body here and a soul there... (Saying this, she pointed outward toward the wall)... I know well that I am one person... but I am outside myself... perhaps there where the 'forces' are..."

She searched with her eyes anxiously along the walls. Then, suddenly, she asked: "What is the aurora borealis? (Very slowly, as if with great effort) I heard about it once; there are patterns and wavy pathways in the sky... (She looked again searchingly along the walls of the room, as if strongly absent)... I hear you, I see you, but somehow far away... at a very great distance... I know very well that I am trembling now, I feel it... but it is not me, it is something else... (after a long pause)... I would like to get rid of this body; it is not me; I want to be where the 'forces' are..."

I was deeply moved in a quite unprofessional manner when I witnessed her experience of the schizophrenic split and depersonalization in such an unequivocal manner....

This was clearly one of the most important sessions in her treatment and, I must add, one of the most instructive happenings in my whole medical experience. Let us pause for a while and try to understand what had happened. To the disinterested institutional psychiatrist, who sees such things happen many times every day, it means "just nothing"; only another of those "crazy things going on in the lunatic." To us, this experience of a living organism is full of meaning and deep secrets. I shall try to connect these phenomena with what we know from orgone-biophysical functioning of the organism. As far as I know, neither psychology nor chemistry nor classical physics could offer any plausible interpretation. 18

Again, the clinical evidence is presented concretely. And again, the material face of the text, the typography, the pauses, elisions in the patient's musings, the italicazations of certain passages, manage the material with the effect of creating spaces, suspensions for the reader's own thoughts. Notably, the numerous emphases on certain words and phrases indicate they are of theoretical or interpretative significance. But they are emphasized 
inconsistently, so their significance is merely suggested. Reich withholds any specific explanation of them, encouraging the reader to work out their meaning himself or herself, and leaving the reader hanging. They become an internal voicing of the text, signifying individuality, eccentricity, personality. Also notable are Reich's dramatic references to himself as scientist. The most sensible reading of his intention, here, is to bring the reader into the text, into collusion with his argument. But the tone of these statements at the same time works against such an intention. They are excesses. The evidence is "utterly incredible", "there can no longer be any doubt about the reality of these facts", they are "full of meaning and deep secrets." The alliance of author and reader in this knowledge is too special. It is exclusive of the professional community of science: "neither psychology nor chemistry nor classical physics could offer any plausible interpretations." So the reader is left on the edge of his own involvement and suspicion, a line which leads toward criticism, self-reliance, and self-consciousness. Finally, the dramatic meaning of this case history is the surprising discovery that schizophrenics are in touch with an otherwise suppressed physiological reality. The streamings of sexual energy, of which they are intensely aware, but which they misname, are more important than ordinary thinking and feeling, truer than normal discourse. This meaning is in 
accord with the consequences, whether intentional or not, of Reich's formal approach - with breaks in the language of the text and the attention of the reader. These both signify and allow moments for deep processes to intervene on the surface of problematic words.

Reich's work in the psychoanalytic movement paralleled a second, equally important, career in working class politics during these years of preparation and writing of Character Analysis. This was a natural consequence of his curiosity and sympathy for the lower class patients he treated in the polyclinic. It was precipitated directly by a notorious incident - the murder of eighty-nine leftist demonstrators and the injury of over a thousand more by Vienna police on July 15, 1927. Reich witnessed the mass demonstration and the ensuing three hour battle, and joined the Austrian Communist Party the same evening.

According to Reich, his political experience decidedly influenced his theoretical and therapeutic work in psychoanalysis.

In 1928, I founded the Socialist society for sex-Counseling and Sex-Research with several viennese physicians. Based on sex-econanic principles, it established the first sexcounseling centers for workers and business employees in vienna.... The society took the position that sexual misery was essentially brought about by social conditions rooted in the bourgeois social order and that it could not be removed entirely but at least could be alleviated by aid to the individual. In addition, information on sexual matters was to be widely circulated among working people. The knowledge underlying this information would be broadened by social work and research on individuals. I reserved the position of scientific director for myself. Six counseling centers were opened immediately, each directed by a 
physician. Three obstetricians placed themselves at our disposal to assist with problem pregnancies. A lawyer also participated.

(What was new about our counseling centers [sexhygiene clinics] was that we integrated the problems of the neuroses, sexual disturbances, and everyday conflicts. It was also new to attack the neuroses by prevention rather than treatment. This depended basically on the handling of sexuality in children and young people..... 19

This clinical work also had political intentions and impact. Reich experienced successes in organizing especially proletarian youth on the issues of sexual freedom comparable to his achievements in therapeutic technique; he inspired dramatic new interest and commitment among thousands of working people, as well as party intellectuals and organizers.

His approach, however, was ultimately unpolitical. The Communist Party leadership in both Austria and Germany calculated that the issue of sexual freedom would deflect revolutionary energies. And influential figures in the psychoanalytic movement feared the potentially destructive consequences - not only to their growing and lucrative private practices, but also from the increasingly reactionary political climate - of such a challenge to conventional morality. Consequently, Reich was expelled from the Communist Party in November, 1933, and from the International Psychiatric Association during its congress in Lucerne in the summer of 1934. Matters of principle and significant theoretical issues were also considered by Reich's opponents during these controversies. But there was 
sufficient opportunism, double dealing, and hysterical resentment against Reich on the parts of the leaderships of these organizations that Reich justifiably felt himself persecuted. $2 \emptyset$

His struggle with these institutions during the early 1930's informed another central concept of Character Analysis, that of the emotional plague. This term describes the tendency of men and women to think and behave domineeringly and destructively, even in the name of reason and morality. It represents Reich's effort to understand his own persecution. He attempted to name that failure whereby the most humanistic, scientifically-minded traditions succumbed to inflexibility, pettiness, and fear in their struggle against fascism.

An essential and basic characteristic of the emotional plaque reaction is that action and the motive of the action never coincide. The real motive is concealed and a sham motive is given as the reason for the action. In the reaction of the natural and healthy individual, motive, action, and goal form an organic unity. Nothing is concealed. This unity is immediately evident. For example: the healthy individual has no other motive for his sexual acts than his natural need for love, and no other goal than its gratification. The ascetic, plagueriden individual, on the other hand, uses ethical codes to justify his sexual debility... The person afflicted with the emotional plague is distinguished from the healthy individual by the fact that he makes his demands of life not only on himself but, above all, on his environment.... Individuals afflicted with the emotional plague do not tolerate views which threaten their armor or unmask their irrational motives. The healthy person is happy to be given an insight into his motives. The plague-afflicted individual is seized by frenzy. When views contrary to his own disrupt his life and work, the healthy individual puts up a strong rational fight for the preservation of his way of life. The plague-afflicted person fights against other modes of life even when they don't concern him in any way 
whatever. He is impelled to fight because he senses the very existence of other ways of life as a provocation. 21

of interest, here, is the special validity Reich's own work relationships have for this concept. Reich engages in a particular mode of generalization, from personal experience to historical significance to scientific concept. This is a peculiar mix of intimacy and grandeur, everyday life and instrumental technique.

No one will take it as an insult if he is told that he is suffering from a cardiac disease or that he is nervous. No one should take it as an insult if he is told that he is suffering from an "acute attack of the emotional plague." We sometimes hear it said among orgonomists: "No sense wasting your time with me today, I'm pesty." In our circle, when someone is afflicted with a minor case of the emotional plague, he deals with it by isolating himself and waiting until the attack of irrationalism passes. In acute cases, where rational thinking and friendly advice are of no avail, orgone therapy is used to remove the infection. It can be seen again and again that such acute attacks of the emotional plague are always produced by a disturbance in the person's love life. They disappear on the elimination of the disturbance. The acute attack of the plague is such a familiar phenomenon to me and to my circle of co-workers that we accept it as a matter of course and deal with it objectively. It is extremely important for students of orgone therapy to learn to perceive acute attacks of the plague in themselves before such attacks go too far, to know how to keep such attacks from getting the best of them, to prevent them from spreading into the social environment and causing damage there, and, by means of intellectual detachment, to wait until they pass. In this way, we succeed in keeping harmful effects in our cooperative work at a minimum. Sometimes such an attack cannot be dealt with and the afflicted person causes a certain amount of harm or even resigns. We take such misfortunes in the same way one would take the acute physical ailment or demise of a beloved colleague. 22

Not only Reich's viewpoint, but also his tone and sense seem wrong, or at least surprising. The very term for 
irrationality, the emotional plague, is peculiar not only for the way in which it suggests emotions to be concrete entities, infections, mechanistic phenomena, but also for its ominous power. The language is at once catastrophic, clinical, and intimate. The sense of the text moves between suggestions of terror and home remedy. The moments Reich is describing with such foreboding are personal and professional jealousies, anger, selfishness, competitive resentments, the stuff that careers, office politics, daily life, and regrets are made of. Again, these represent a disjuncture in the text. They strike the reader as improprieties, puzzlements within a scientific discourse as the interpenetration of text and life, science and intimate charm, reason and special pleading.

Reich's description is also utopian, unrealistic, a misleading account of his relationships with his workers, which were actually much cloudier. From 1935 until his death, Reich attempted to compensate for his homeless, outcast predicament as a scientist by constructing organizations of his own. The last of these, the orgone Institute, which Reich founded after emigrating to New York in 1941 and ultimately settling at Rangeley, Maine, became consumed repeatedly with its director's sexual unfaithfulness and jealousy. He had affairs with patients, co-workers, and co-workers' wives; and he projected bad feelings with destructive consequences. 
Always, in times of stress, one of Reich's very human failings came to the foreground, and that was his violent jealousy. He would always emphatically deny that he was jealous, but there is no getting away from the fact that he would accuse his wife of infidelity with any man who came to his mind as a possible rival, whether colleague, friend, local shopkeeper, or casual acquaintance. It was one of those strange contradictions in Reich's make-up, and another one that must have been founded on some basic, unresolved feelings of insecurity, because there were no reasons in fact for these jealousies. However, they seemed to provide him with what he must have felt was a rational outlet for his anger against the world. 23

He also dominated his staff at the Institute, unable to work with anyone except the most obedient and unquestioning.

I think, theoretically, he expected people to know what they were doing, to follow him in his pursuits because they knew he was right or that his theories were correct or because they felt about these things the same way he did. But in practice he overlooked the fact that few of those around him were equipped, emotionally or otherwise, to follow him or to understand his theories. They would follow, if they did, out of admiration, out of love, out of blind loyalty or sometimes, out of fear of being kicked out of his orbit. The power of his personality was enormous, and was difficult to understand. It was this inflexible attitude of his, more than anything else, that again and again, lost him friends and co-workers. 24

The direction of Reich's career after his expulsions from the communist and psychoanalytic movements was toward a mechanical explanation of this sort of irrational feeling. His theoretical work became increasingly projective, an identification of historical with personal conflicts, and their universalization into a wonderfully imaginative and suggestive, but eccentric, physics and cosmology. In an analogy to the autonomic undulations of the body musculature during orgasm, Reich postulated a quantifiable flow of electrical energy throughout the human body and all living 
organisms. This also is a wave-like motion, an alternation between the interior and exterior limits of the body. In 1934, he attempted to document this by measuring changes in the skin potential of his patients' erogenous areas. He found correspondences among a tendency of the deep functioning of the body toward the periphery, increased skin charge, and erotic and pleasurable feelings on one hand, and movement away from the periphery, decreased skin charge, and subjective feelings of unpleasure or anxiety on the other. In 1935, Wilhelm Hoffmann, a German physiologist collaborating with Reich, attempted to test these findings and Reich's general theory by measuring the skin potential of schizophrenic patients. Their emotional withdrawal should have been manifested in lower skin potential measurements, especially in the conventional sex-sensitive areas of their bodies. But Hoffmann was unable to reproduce any difference at all, and Reich angrily repudiated his colleague's experiments.

In new observations with plant tissue in solution, Reich argued that the erotic-like pulsations of disintegrating cells were evidence of a fundamental life form, which he named the bion. Critics attempting to replicate his studies dismissed his claims, insisting he had witnessed Brownian movement, the tendency of small particles to oscillate as a result of their collision with neighboring molecules. Reich's resentment and isolation grew. 
In 1941, he met with Albert Einstein and attempted to explain the bion, as well as further discoveries: the release of a bluish light and light corpuscles concomitant to the creation of bions by means of heating and disintegrating beach sand in solution; also, the seeming accumulation of heat within specially constructed boxes of celotex, steel and glass wool, and sheet iron. Reich described these phenomena as the release and absorption of a basic life energy associated with the bion, which he named orgone energy. He reported still more experiments, in which cancer-afflicted rats placed inside the orgone accumulator boxes experienced significantly increased life spans.

Einstein was initially excited by Reich's visit.

He also promised to support Reich's discovery if the findings were verified. Before leaving, Reich suggested that Einstein could now understand the rumor that he was insane. Einstein replied that he certainly could....

Subsequently, he wrote Reich that he had limited his efforts to the temperature difference because of his inability to exclude subjective impressions regarding the light manifestations of orgone energy. Initially, he found the accumulator temperature regularly higher.... However, an assistant had offered the explanation that this difference was due to convection currents between the air over the table and the air of the room as a whole....

To Einstein's credit, he thought seriously for awhile and he experimented. But once satisfied with his own explanation, he believed the matter "completely solved", and showed no wish to pursue Reich's further experiments. 25

In desperation, Reich pressed Einstein to give public support for his work. The physicist "responded angrily about having his name used for advertising purposes."26 Reich reacted with the accusation "that Einstein's sudden 
indifference was part of a general communist-inspired conspiracy against Reich's work.27

Also during 1941, Reich began experimenting with sick human beings in the accumulator boxes. Patients reported experiencing feelings of increased well-being, as well as decreased pain. A number of Reich's cancer patients claimed remission and significant shrinking of tumors to allow successful surgery.

During the later 1940's and into the 1950's, he further elaborated the theory of orgone energy as an antidote to an imminent planetary disaster, manifested in such phenomena as nuclear radiation, the emotional plague, weather disturbances, and flying saucer sightings. His son Peter reveals a sense of Reich's work and thinking in these years, which maintains, still, a disturbing tension among child's play, paranoid fantasy, and scientific intuition.

I felt around in the sand near the base of the tree until I found the buried metal plate. I dug the sand away from the plate and lifted it up. Beneath it was a small hole in the ground. I reached into the hole carefully, because there might be scorpions, and took out a small bundle wrapped in black banana skins. I laid the bundle on the metal plate and slowly unwrapped the bright green glow-in-the-dark yoyo. It was a beautiful bright yoyo and I was sorry I couldn't play with it. I slipped the loop over my finger to do a few whirls with it but then I remembered that Daddy said it was bad for me. I put it back onto the metal plate and went into the kitchen for water. I poured the water into the hole to loosen up the dirt and then I started digging.

Daddy said I had to bury the glow-in-the-dark yoyo because the glow stuff was deadly just like fluorescent light. Glow-in-the-dark light was bad energy and it didn't mix with Orgone Energy, which was good energy. Daddy was trying to kill the bad energy in the atmosphere. Bad energy came from flying saucers and bombs. The cloudbuster 
cleaned the atmosphere of the deadly orgone - we called it DOR - and fought the flying saucers. Only we called the flying saucers EAs. It was initials. The $E$ stood for something and the stood for something. Daddy told me what it was but I forgot. We had names for a lot of stuff. The EA's energy was like glow-in-the-dark enery and it made us sick.

We were all sensitive to strange energy things, especially my sister Eva. Fluorescent light was really bad, and Eva could never understand how people could survive in office buildings with dead light energy. The same with glow-in-the-dark watches or television. It got so Eva could tell if someone was wearing a glow-in-the-dark watch just by feeling the energy around him. She could feel tv that way too and it made her sick. She was the one who spotted my green glow-in-the-dark yoyo. One day when I came near her she felt funny and got a little green herself. She asked me what I was wearing and where I had been. Then I took out the glow-in-the-dark yoyo and started yoyoing and she almost fainted. That was when Daddy said I had to bury it. 28

In order to support his cloudbuster - a machine designed both to control the weather and defend against invasions from outer space - and other orgone energy experiments, Reich began marketing the accumulator boxes; this had disastrous consequences. In 1946 and 1947, he came under attack in two very damaging articles in The New Republic: one, a review of Reich's The Mass Psychology of Fascism, "accused Reich of 'utter contempt for the masses because he stressed their mysticism and incapacity for freedom""; the second, "The strange Case of Wilhelm Reich", charged that "'The man who blames both neuroses and cancer on unsatisfactory sexual activities has been repudiated by only one scientific journal.'"29

By the end of 1948 it became obvious that a concerted effort was being made by the American Psychiatric Association against the spreading of psychiatric orgone therapy. Several psychiatrists who had been trained by 
Reich and had begun to practice psychiatric orgone therapy were dismissed from the staffs of hospitals where they worked after they refused to give up a therapy which they thought beneficial to their patients. Others were denied promotions in professional associations. Still others, in private practice, were approached by the A.P.A. and advised to sever their connection with Reich. All these men, graduates of medical schools of high standing and respected members of professional organizations, had come to find in orgone therapy a better way of helping their patients - and on that basis preferred to sever their connection with the established medical associations rather than with Reich. Reports came to the Orgone Institute that in lectures and courses given by members of the American Psychiatric Association and the New York Psychiatric Association derogatory remarks about Reich and orgone therapy crept in again and again; and rumors made the rounds that Reich was in a mental hospital. 30

In February, 1954, the Food and Drug Administration brought an injunction against marketing the orgone accumulators, charging that they were being claimed fraudulently to cure cancer. Reich promptly defied the ban, and was tried and convicted for contempt in 1956. Despite improprieties and contradictions in the government's case, and his obvious poor health, Reich argued in his defense only that the government had no jurisdiction over basic issues of science, and that he was the victim of a Red Fascist conspiracy in particular, and the emotional plague in general. With no defense made to the specific charge of criminal contempt, Judge George Sweeney reluctantly sentenced Reich May 3, 1956, to two years in prison. In August, federal agents destroyed the orgone boxes in Reich's possession, and burned his books and papers. Reich died in his sleep November 3, 1957 in Lewisburg Federal Penitentiary. 


\section{CHAPTER III}

\section{ENDNOTES}

1. This chapter draws heavily on Myron Sharaf, Fury on Earth: A Biography of Wilhelm Reich (New York, 1983). It also depends on Ilsa ollendorff Reich, Wilhelm Reich: $A$ Personal Biography (New York, 1969); Peter Reich, A book of Dreams (New York, 1973); as well as Wilhelm Reich's own reminiscences in people in Trouble: Volume Two of the Emotional plaque of Mankind, translated by Philip Schmitz (New York, 1976). These sources agree as factual accounts of Reich's life. Sharaf and Ilsa and Peter Reich suggest the domineering aspects of Wilhelm's personality, but the emphasis on this is my interpretation. The sources tend to be more cautious in evaluating Reich's emotional life than I have been.

2. Sharaf, p. 39.

3. Ilsa Ollendorff Reich, pp. 3-4

4. Sharaf, p. 37.

5. Ilsa Ollendorff Reich, p. 3.

6. Ibid., p. 5 .

7. Sharaf, p. 39.

8. Ibid., pp. $39-40$.

9. Erik H. Erikson, quoted in Sharaf, p. 45.

10. Sharaf, pp. 42-43.

11. Ilsa Ollendorff Reich, p. 4.

12. Sigmund Freud, "Papers on Metapsychology (1915)", in The standard Edition of the Complete Psychological Works, v. xiv, edited and translated by James strachey (London, 1957), pp. 175-176.

13. Wilhelm Reich, Character Analysis, p. 13.

14. Ibid., p. 48 . 
15. Ibid., p. 361.

16. Ibid., pp. 293-294.

17. Ibid., pp. 238-239.

18. Ibid., pp. 434-436.

19. Wilhelm Reich, people in Trouble, pp. 73, 107-168. 20. Ilsa Ollendorff Reich, pp. 23 and 32 .

21. Wilhelm Reich, Character Analysis, pp. 506-507.

22. Ibid., p. 505.

23. Ilsa Ollendorff Reich, p. 45.

24. Ibid., p. 24.

25. Sharaf, p. 286.

26. Ibid., p. 287.

27. Ilsa Ollendorff Reich, p. 57.

28. Peter Reich, pp. 12-13.

29. Sharaf, pp. 360-361.

3ø. Ilsa Ollendorff Reich, pp. 9ø-9l 
CHAPTER IV

GENERATION AND FIELD OF DISCOURSE

Thus far, I have attempted to understand certain analogous contradictions in Reich's life and the text of Character Analysis - failures of memory, erotic moments, an eccentric science - as manifested formally and signifying liberation. I want to proceed to a comparable problem. This is the relationship of the book to its social context, to the special sense of the world experienced by Reich and his generation. This a correspondence between the authoritarian tendencies of German and Austrian society and culture during the imperial and interwar period, and a central concept of Reich's - the genital character type. The interpenetration of milieu and text appears as the attempt to objectify reason in nature. And again, the writing itself signifies a basic motive to overcome habits of domination and affirm freedom and tolerance. This is evident formally in Reich's use of identity statements. My discussion proceeds from a description of some common psychological and social experiences shared by Reich and other Central Europeans of his era, to some common cultural values, and to some common characteristics of anti-fascist psychoanalytic writing. 
Peter Loewenberg's concept of the youth cohort is useful in delineating some attributes of Reich's generation - of the social, intellectual, and psychological climate within which character Analysis was written. He defines a cohort as

The aggregate of individuals within a population who have shared a significant common experience of a personal or historical event at the same time. 1

Each individual carries the effects of this significant experience for his or her entire life. Loewenberg bases his analysis of twentieth century German political attitudes on the childhood insecurities suffered by those youth who were aged eighteen to thirty in 1933, who were born and raised during the First World War, and who represented nearly half the membership of the Nazi Party, the party's "first breakthrough into the masses." 2

Common experiences in childhood, in psychosexual development, and in political socialization .... led to similar fixations and distortions of adult character. The specific factors that conditioned this generation include the prolonged absence of the parents, the return of the father in defeat, extreme hunger and privation, and a national defeat in war, which meant the loss of the prevailing political authority and left no viable replacement with which to identify. 3

The consequences of these pressures included a tendency "toward violent, aggressive, 'acting out' behavior", and toward "the devices of splitting and projection - the good and the bad upon whom one can gratify aggressive feelings." 4

The psychological symptoms of regression to phases of ego functioning "fixed" by the traumata of a childhood in war 
included responding to internal personal stress with externalized violence, projecting all negative antinational or anti-social qualities onto foreign and ethnic individuals and groups, and meeting frustrations that would otherwise be tolerated with patience and rationally approached for solutions with a necessity for inmediate gratification. The political expression of weakened egos and superegos that fostered regression was manifest not only in turning to violence but most especially in the longing for a glorified and idealized but distant father who is all-knowing and all-powerful, who preaches military virtues and permits his sons and daughters to identify with him by wearing a uniform and joining combat in a national cause. 5

Reich and many of his patients, of course, were born into the generation previous to this. But his own cohort shared similar economic stresses, especially those caused by the mass movement of people from Eastern and Southern Europe into the industrial cities of Germany and Austria-Hungary. Reich was exposed to the psychological pressures of the war as a combat officer and to the after-effects of the German Revolution of 1918 as a Communist Party organizer. And, as we have seen, he suffered severely the trauma of parental loss. So Loewenberg's concept of generation helps illuminate not only the climate of thought and experience, but also the individual sensibility, which inform the text.

The concept of national character is similarly useful. In an anthropological study of Germans who survived World War Two, David Rodnick delineates a number of significant traits, indicating a basic pattern of submissiveness, obedience, insecurity, and yearning for community.

[A] dependence upon others for affection is present throughout German society and may well arise from the extremely warm and submissive relation of parents in German 
family life. The experiences of most Germans after the adolescent years tend to negate this pattern, but the desire for affection remains. The insecure world of the adult, where personal goals are difficult to realize, where hopes can be easily shattered, where social status can be tenuous, and hostility is met far more often than friendliness, makes the German feel that he must not show any softness but be hard toward his fellow man. In a world where, at a cost to his own ego, he must constantly defer to individuals above him in social status, he rarely feels personally secure. He learns to conform to the prevalent patterns because he will be punished if he does not, but underneath there is a desire to feel that he has not fear but liking for those above him, and that they in turn like him. 6

German children were shown constant affection by both parents from infancy; until the age of three they were held by their mothers for much of their waking hours. Their physical needs were completely ministered to. warmth and security extended to these children's entire experience.

Even strangers are brought into the world of intimacy surrounding the child as "uncles" and "aunts", and the child is encouraged to look upon everyone who enters the family circle as being friendly toward him. 7

In addition, discipline was stressed. "Among all classes, toilet training begins when the infant is about five months old." 8 German children learn politeness, cooperativeness, a regard for others, and egalitarianism within the family environment. The contradictions to adult experience - of status preoccupations, economic struggle, and alienated affections - became mediated by strong class consciousness and intense friendships formed in adolescence.

The German adolescent feels a strong bond between himself and others of his age. He would like to see a society developed exclusively for adolescents to protect them against the difficulties of living in a world controlled by their elders who make no provision for the youth to replace 
them through assistance, guidance, and gradual selfAnd it was compensated in part by early sexual experience. Middle class boys were generally sexually active by the age of fourteen, usually with prostitutes or servants. Proletarian youths tended to remain innocent longer, unable to obtain prostitutes until they became wage-earners, usually at age seventeen. Early engagements and pre-marital sex were common; girls were expected to provide sexual favors in exchange for the companionship of boys. Orgasm and sexual satisfaction among middle class women were rare. Although marriages were generally life-long arrangements, about half of bourgeois German men continued to have mistresses or frequent prostitutes. This was not economically possible for working men, who tended to be less impotent and more affectionate with their wives. These patterns of unfulfilling sexual arrangements and of submission to authority in family life recall Reich's own childhood experiences and point to his condemnation of the wide-ranging consequences of patriarchy and repression.

The experiences of adolescents cannot be overemphasized as factors in the creation of German culture and society during Reich's period - which was marked politically by the development of mass organizations outside of traditional parties, and generally by strong authoritarian, communal, and erotic features. This is most 
notably evident in the impact of the youth movement in Germany and Austria during the decades from 1890 and 1930. Reich himself joined an Alpine club during his student years in Vienna. And certain features of the Volkish movement are reflected in his work. A significant one is the emphasis placed on liberating activity. Walter Laqueur, in his study of young Germany, recalls

"Nobody but the German knows in which direction he is moving." When I first read those words [of Martin Voelkel, a youth leader], my memory was taken back to something that had happened to me in 1934. I was visiting one of the brand new German labour camps at Rendsburg in SchleswigHolstein, in an attempt to understand the Hitler Youth. That evening, in the youth hostel, we got into a fierce argument and $I$ accused the Nazis of leading Europe to destruction. At this point, my opponent, a handsome, uniformed blond, drew himself up and shouted, "At least Germany is leading and you are dragging along behind. "1ø

Besides its nationalism, certainly the most evident characteristic of Volkish thinking is its faith in the transformative power of action - in and of itself - over the future. It is a utopian mode of thought, based on a yearning to negate the present and open up time for the emergence of potentiality and authenticity. In this conviction, the youth movement voiced an "unpolitical protest against bourgeois civilization's lack of vitality, warmth, emotion, and ideals."ll Equally characteristic was its emphasis on leadership. This was understood as a natural, sexual quality, with physical beauty and grace its emblems. An important experience in many of these groups was ecstatic surrender - often to music and dance, or to the 
erotic appeal of the group leader. Protests against sexual repression were often found in their programs.

These attitudes found their most significant historical expression in those undercurrents of Weimar society which apotheosized war, which valued leadership, action, and erotically charged physical courage and grace as absolutes. The German army toward the end of World War One recruited and promoted from the ranks an enormous number of officers of a special type, young, unmarried, often former athletes, and without regard to class background. Trained to function in a horrifying war, commissioned, and given status counter to traditional social constraints, these men became after the armistice the leaders of a mass of "fighters who could not be debrutalized."12 An estimated 200,000 to 400,000 veterans, ruthless, arrogant, and without attachments, joined the Free corps, the private armies used against the Spartacus Uprising and the chronically unstable Weimar Rupblic. In the words of the writer Ernst von Salomon:

The war could not release them from its grip... The most active part of the Front marched simply because it had learned to march. It marched through the cities enveloped in a cloud of sullen rage - a cloud of vaulting, purposeless fury - knowing that now it had to fight, to fight at any cost... This then was the one problem of the Free Corps fighter: to give his utmost so that the real meaning of the war could be made manifest to the very limit of his power. 13

As a social, psychological, and cultural force, the German war veterans resemble the Volkish youth in their critical 
attitude toward bourgeois liberalism and they resemble Reich in their valuing of an activity beyond words and thought as a form of liberation. Again, in von Salomon's words:

We were cut off from the world of burgerlich norms... The bonds were broken and we were free. The blood surging through our veins was full of a wild demand for revenge and adventure and danger... We were a band of fighters drunk with all the passions of the world; full of lust, exultant in action. What we wanted, we did not know. And what we knew, we did not want! War and adventure, excitement and destruction. An indefinable, surging force welled up from every part of our being and flayed us onward. 14

This pure resentment, at base objectless, exemplifies the wellspring of psychological projection that pervaded Reich's ego. Social pressures, individual insensitivities, and emerging erotic desires all combined to form a typical mode of thinking. It characteristically confused rebellious yearnings with habits of sadistic domination. This seems to me similar to what we have seen as a significant contradiction in Reich's own life and work.

These aspects of Central European society and culture in general - insecurity, tendencies toward domination and projection, the eroticization of political issues - recall more than contradictions and characteristics of character Analysis. A struggle toward consciousness of these same issues is typical of a special realm of discourse - the psychoanalytic critique of fascism. Reich's historical reputation to a large extent derives from his own pioneering work - and Character Analysis is illuminated by its place in this tradition. I want to proceed to describe a number 
of these important writings in the hope they might point up the relative historical significance of Reich's contradictory tendencies toward 1 iberation and domination.

Perhaps the most widely known work in this tradition is Erich Fromm's Escape from Freedom. Fromm attempts to define a historically important feature, a typology of the character structure of the masses. This is only in some respects similar to Reich's. It is independent of any theory of material instincts. The most significant neurotic type for both writers is the sadomasochist. But Fromm emphasizes ego conflict rather than sexuality.

The difference between the perversion and masochistic character traits lies essentially in the following: In the perversion the trend to get rid of one's self is expressed through the medium of the body and linked up with sexual feelings. While in moral masochism, the masochistic trends get hold of the whole person and tend to destroy all the aims which the ego consciously tries to achieve; in the perversion the masochistic strivings are more or less restricted to the physical realm; moreover by their amalgamation with sex they participate in the release of tension occurring in the sexual sphere and thus find some direct release.

The annihilation of the individual self and the attempt to overcome thereby the unbearable feeling of powerlessness are only one side of the masochistic strivings. The other side is the attempt to become part of a bigger and more powerful whole outside of oneself, to submerge and participate in it. This power can be a person, an institution, God, the nation, conscience, or a psychic compulsion. By becoming part of a power which is felt as unshakably strong, eternal, and glamorous, one participates in its strength and glory. One surrenders one's own self and renounces all strength and pride connected with it, one loses one's integrity as an individual and surrenders freedom; but one gains a new security and a new pride in the participation in the power in which one submerges. 15

Fromm also opposes the neurotic to an ethically normative, 
rational, free personality type similar to Reich's genital character.

With regard to single concepts we have shown that to the sado-masochistic character, for example, love means symbiotic dependence, not mutual affirmation and union on the basis of equality; sacrifice means the utmost subordination of the individual self to something higher, not assertion of one's mental and moral self; difference means difference in power, not the realization of individuality on the basis of equality; justice means everybody should get what he deserves, not that the individual has an unconditional claim to the realization of inherent and inalienable rights; courage is the readiness to submit and endure suffering, not the utmost assertion of individuality against power. ${ }^{16}$

Fromm, however, makes a very broad historical and social analysis on the basis of an unmediated analogy to clinical findings.

The physiologically conditioned needs are not the only imperative part of man's nature. There is another part just as compelling, one which is not rooted in bodily processes, but in the very essence of the human mode and practise of life: the need to be related to the world outside oneself, the need to avoid aloneness. 17

There is a certain advantage to this. Evidence of social unreason and domination need not be tied to actual emotional disorders nor their physiological aetiologies. Consequently fascist tendencies can be predicated or explained of any group or individual impressionistically. There is also a certain problem. Critique loses the force of a natural necessity, and becomes a transparent projection of purely personal concerns. This is true of Fromm's history-making in Escape from Ereedom, his identification of fascism with the Protestant Reformation as a class response to crisis, 
insecurity, and change.

Thereby the new religious doctrines not only gave expression to what the average member of the middle class felt, but, by rationalizing and systematizing this attitude, they also increased and strengthened it. However, they did more than that; they also showed the individual a way to cope with his anxiety. They taught him that by fully accepting his powerlessness and the evilness of his nature, by considering his whole life an atonement for his sins, by the utmost self-humiliation, and also by unceasing effort, he could be loved by God and could at least hope to belong to those whom God had decided to save. Protestantism was the answer to the human needs of the frightened, uprooted, and isolated individual who had to orient and to relate himself to a new world. The new character structure, resulting from economic and social changes and intensified by religious doctrines, became in its turn an important factor in shaping the further social and economic development. 18

However suggestive this might be as an historical insight, it is undetermined by any empirical constraints. protestantism doubtlessly was also the very human response of the strong, self-assured, secure, flexible, and loving to their historical situation - of genital as well as sadomasochistic characters - and informed social institutions typified by freedom as well as economic discipline. So at times Escape from Freedom seems itself an exercise in intolerance - and certainly subject to the same strains and contradictions as Reich's work.

G. M. Gilbert, in The Psychology of Dictatorship, explains fascism as an interaction of the individual psychosexual characteristics of its leadership with social stresses and cultural norms. Unlike fromm, he relies on clinical evidence - prison interviews and psychological 
tests of Goering, Hess, Frank, Ribbentrop, and Hoess. Of course, this was not an ideal therapeutic situation; Gilbert did not face his subjects with the sympathy of the physician seeking an understanding that comes with cure, but as an interlocutor assuming criminal guilt. And his analysis of Hitler had to be secondhand. But he is careful with the complex mediations between individual personality and historical events.

This confusion of values and purposes at the very outset of the National socialist movement was largely determined by the multiplicity of Hitler's aggressive needs and ambivalent group identifications. It also accounted for the extreme variety of personalities and motives among the followers, rendering any categorical judgements on the character of the Nazis extremely unreliable. 19

Gilbert understands psychopathic leadership as a type of response to real social contradictions. For example, he notes a characterological symptom of Hitler which is reminiscent of Reich's discussion. His relationships with women were supposedly abnormal. Although there is no good evidence to believe that he committed sexual perversions, he showed an "inhibited and strained... inordinate politeness and show of gallantry."

[He] would kiss the hand of an ordinary unmarried girl, inappropriately imitating the gesture reserved for Junkers' and ministers' wives. 20

This quirk was the trivial acting out of a profound class contradiction, a subtle aggression, and an impropriety that reflected a yearning for class reconciliation in the midst of extreme differences of status. A similar dynamic was at 
work in Rudolf Hess.

The palpable psychopathology in Hess' case appeared to be directly related to [a] conflict of social values. Though it undoubtedly had its roots in his early emotional development, the breakdown into outright hysterical and paranoid symptoms was precipitated by social conflict: the incompatibility of humanitarian ideals and aggressive ethnocentricity. 21

Perhaps Gilbert's most striking evidence comes from Rudolf Hoess, commander of the extermination camps. Hoess exhibited an unusual poverty of affect; sex played almost no part in his life, he showed no passion toward his wife, and never masturbated nor felt the desire to. Hoess' distraction matched his historical role.

The five years of solitary confinement in Dachau virtually completed the withdrawal process. By the time he became "desensitized" to the task of extermination, he was a walking inhuman robot, utterly devoid of human empathy, yet functioning intellectually on a high level of mechanical efficiency. 22

Gilbert's point is that social and cultural contradictions fed a monstrously criminal political activity, because of their extreme demands on normal psychological adaption functions. It is a point that surprisingly seems to extend sympathy and understanding even to fascists as bound in ahead of social, psychological, and historical fact.

Erik H. Erikson, in "Wholeness and Totality - a Psychiatric Contribution" to Carl J. Friedrich's symposium on totalitarianism, approaches the problem of fascism with still stronger therapeutic empathy.

I begin with the assumption that totalitarianism is based on universal human potentialities and is thus related to all aspects of human nature, wholesome and pathological, 
adult and infantile, individual and societal. Totalitarianism has often been a near reality: it has merely waited for "its" historical moment.... Only such historical perspective can give the proper measure of the different degrees and kinds of ideological involvement on the part of the many types that make up a totalitarian state: fanatic apostles and the shrewd revolutionaries; lonely leaders and oligarchic cliques; obedient bureaucrats and efficient managers, soldiers, and engineers; sincere believers and sadistic exploiters; willing followers, apathetic toilers, and paralyzed opponents; unnerved victims and bewildered would-be and could be victims. 23

Fascism as a historical moment is possible because it draws on typical experiences in individual development. The normal healthy alternation between various given poles of living and feeling - Erikson mentions an infant's happy pattern of waking and sleeping as an example - gives way at critical times in any human life to what Erikson calls total realignments.

Violent loves and hates and sudden conversions and aversions share with the child's fetishism and fears such factors as the exclusive focusing of a set of (friendly or unfriendly) affects on one person or idea; the primitivization of all affects thus focused; and a utopian (or cataclysmic) expectation of a total gain or a total loss to come from this focus...

While such realignments may seem to appear suddenly, they develop slowly. Only uncommonly aware and brave people know about themselves what psychoanalysis reveals in others, and particularly patients - namely, how strong and systematic are man's proclivities and potentialities for total realignments, often barely hidden behind one-sided predilections and convictions, and how much energy is employed in inner defenses against a threatening total reorientation in which black may turn into white and vice versa.... At any rate, we have learned to understand such realignments as readjustments on a more primitive level, made necessary by increased anxieties, especially of infantile origin, and called forth by acute life crises. 24

Perhaps the most common of these totalistic adjustments is 
the experience of romantic love, the selection of a single object as the focus of all affect and self-identification. The origin of these experiences is the infant's total dependence on its mother and the total rage it can suffer in moments of powerless, frustrated impoverishment. Periods of radical social change can throw an entire society, and especially its youth, back to a condition within which this rage predominates.

Where historical and technological developments severely encroach upon deeply rooted or strongly emerging identites (i.e., agrarian, feudal, patrician) on a large scale, youth feels endangered, individually and collectively, whereupon it becomes ready to support doctrines offering a total inmersion in a synthetic identity (extreme nationalism, racism, or class consciousness) and a collective condemnation of a totally stereotyped eneny of the new identity. The fear of loss of identity which fosters such indoctrination contributes significantly to that mixture of righteousness and criminality which, under totalitarian conditions, becomes available for organized terror and for the establishment of major industries of extermination. Since conditions undermining a sense of identity also fixate older individuals on adolescent alternatives, a great number of adults fall in line or are paralyzed in their resistance. 25

Erikson opposes the experience of totality with what he names wholeness; this is another ego development norm, emphasizing flexibility and tolerance, and similar to Reich's genital character.

There seems to be something like a movement from Fromm to Gilbert and Erikson of increasing sympathy for the human experience that makes the mass psychology of fascism possible. This is still clearer in Georges Bataille's "The Psychological Structure of Fascism." Bataille proposes a 
typology of social existence defined by the categories of homogeneous and heterogeneous. Homogeneous society is useful, productive, rational; it is one of concrete cash and legal relationships, continuities, smooth, and interchangeable. "In the contemporary period, social homogeneity is linked to the bourgeois class by essential ties." 26 The heterogeneous is, on the other hand, related to the unconscious and the masses. Its characteristics include disruptions, shocks, "violence, excess, delirium, madness", despair, and revulsion. 27

The nauseating forms of dejection provoke a feeling of disgust so unbearable that it is improper to express or even to make allusion to it. By all indications, in the psychological order of disfiguration, the material poverty of $\operatorname{man}$ has excessive consequences. ${ }^{28}$

It is a manifestation of affect.

It presents itself as a charge, as a value, passing from one object to another in a more or less abstract fashion, almost as if the change were taking place not in the world of objects but only in the judgments of the subject. 29

It is the realm of the sacred, the erotic, of poverty, and filth. The two categories are mediated historically in kingship, which represents both the rational, regular activities of the state, and the irrational attributes of domination, absolute freedom, and war-making. Fascism is a peculiar modern form of kingship, in which the leader partakes of "assuming in complete freedom the imperative character of action", as well as the sacred qualities of nature and the nation. 30 This is the basis of its appeal, 
its affective connection to the masses. However, fascist domination remains unstable, ironically, because of its homogeneous elements; its political authority continues to depend on administrative, juridical, and economic functions. Bataille characterizes fascism as an incomplete exploitation of heterogeneous aspirations.

Thus the upper part of the heterogeneous region is both imobilized and immobilizing, and only the lower part formed by the impoverished and oppressed classes is capable of entering into movement. But, for the latter, passive and oppressed by definition, the fact of entering into movement represents a profound alteration of their nature: in order to take part in a struggle against the sovereign agency and the legal homogeneity oppressing them, the lower classes must pass from a passive and diffuse state to a form of conscious activity; in Marxist terms, these classes must become aware of themselves as a revolutionary proletariat. This proletariat cannot actually be limited to itself: it is in fact only a point of concentration for every dissociated social element that has been banished to heterogeneity. It is even possible to say that such a point of concentration exists in a sense prior to the formation of what must be called the "conscious proletariat": the general description of the heterogeneous region actually implies that it be posited as a constitutive element of the structure of a whole that includes not only imperative forms and impoverished forms but also subversive forms. 31

In other words, the intuitions, the drives, the affects that erupt in fascism are not so much pathologies as subversive, liberating powers.

An organized understanding of the movements in society, of attraction and repulsion, starkly presents itself as a weapon - at this moment when a vast convulsion opposes, not so much fascism to cormunism, but radical imperative forms to the deep subversion which continues to pursue the emancipation of human lives. 32

The work of Max Horkheimer in effect extends this sympathy by means of a thoroughgoing radical critique of all 
current social relations as essentially fascist - as moments of domination. These include the concepts of reason, character development and youth, sexuality and the family, and the touchstone of fascist domination, racism. For example, in Eclipse of Reason, he argues that the very concept of rationality in western philosophy has become purely instrumental, divorced from moral decisions and absolute values, and harnessed to economic production, class, authority, and the destruction of nature.

Having given up autonomy, reason has become an instrument. In the formalistic aspect of subjective reason, stressed by positivism, its unrelatedness to objective content is emphasized; in its instrumental aspect, stressed by pragmatism, its surrender to heteronomous contents is emphasized. Reason has become completely harnessed to the social process. Its operational value, its role in the domination of men and nature, has been made the sole criterion.... Any use transcending auxiliary, technical summarization of factual data has been eliminated as a last trace of superstition. Concepts have become "streamlined", rationalized, labor-saving devices. It is as if thinking itself had been reduced to the level of industrial processes, subjected to a close schedule - in short, made part and parcel of production. 33

This subjugation of reason signals for Horkheimer something more than a problem in the history of epistemology; rather, it adduces a historical system of class relationships which function uniformly as a totality. Its class character reveals how reason is compromised as a mere tool of domination.

Insight, for example, may be an important factor in the development and continuance of society; it may even be the immediate ground of socialization, as many theories of Enlightenment times or a psychologist like freud claims. Yet the whole psychic apparatus of members of a class society, in so far as they do not belong to the nucleus of 
privileged people, serves in large measure only to interiorize or at least to rationalize and supplement physical coercion. The so-called "social nature" of man, his self-integration into a given order of things, whether the ground of this order be pragmatic, moral, or religious, is essentially reducible to the memory of the acts of force by which men were made "sociable" and civilized and which threaten them still if they become too forgetful. 34

It also reveals the knot of contradictions that make fascist responses the typical human experience. For example, the rage and hatred of civilization typical of a fascist youth is not simply an irrational projection. It is more an unsuccessful but understandable attempt to overcome "the renunciation of instinctual urges expected from him.n35 Adolescent revolt is based on the intuition of the wrongness of class relationships.

What fills the adolescent with distress is, above all, his dim and confused realization of the close connection or near-identity of reason, self, domination, and nature. He feels the gap between the ideals taught to him and the expectations that they arouse in him on the one hand, and the reality principle to which he is compelled to submit on the other. His ensuing rebellion is directed against the circumstance that the air of godliness, of aloofness from nature, of infinite superiority, conceals the rule of the stronger or of the smarter. 36

The young have two options in their self-creation of character: either a life of loneliness and confrontation, the inevitable consequences of their expressions of truth and passion; or one of submission. Mass acquiescence to authority gravitates between these two poles of ultimately meaningless aggression and reconciliation, both of which are merely forms of self-obliteration. In this scheme, race 
murder demonstrates in its purest form the frustration of affect, domination, and the absurdity of class.

The rights of man were designed to promise happiness even to those without power. Because the cheated masses feel that this promise in general remains a lie as long as there are still classes, their anger is aroused. They feel mocked. They must suppress the very possibility and idea of that happiness, the more relevant it becomes. Wherever it seems to have been achieved despite its fundamental denial, they have to repeat the suppression of their own longing. Everything which gives occasion for such repetition, however unhappy it may be in itself - Anasver or Mignon, alien things which are reminders of the promised land, or beauty which recalls sex, or the proscribed animal which is reminiscent of promiscuity - draws upon itself that destructive lust of civilized men who could never fulfill the process of civilization. Those who spasmodically dominate nature see in a tormented nature a provocative image of powerless happiness. The thought of happiness without power is unbearable because it would then be true happiness. 37

To conclude this review of the intellectual context of Character Analysis, I am going to note some aspects of Herbert Marcuse's work of the 1930's and 1940's. Like Horkheimer, he views fascism as a general consequence of social class, as a totality which nevertheless signals possibilities for liberation. He links liberation with absolute ethical values and non-instrumental reason.

A theory of society is rationalist when the practice it enjoins is subject to the idea of autonomous reason, i.e. to the human faculty of comprehending, through conceptual thought, the true, the good, and the right. Within society, every action and every determination of goals as well as the social organization as a whole has to legitimate itself before the decisive judgment of reason and everything, in order to subsist as a fact or goal, stands in need of rational justification. 38

Bourgeois ideology, by abandoning autonomous reason and viewing human freedom as exercised in individual market 
decisions and their aggregate as natural mechanisms, prepares the ideational basis for fascism.

Through this privatization of reason, the construction of society in accordance with reason is deprived of the end which is supposed to provide its goal (just as in irrationalism it is deprived of its beginning through the functionalization of reason). Thus, precisely the rational determination and condition of that "generality" in which the "happiness" of the individual is supposed to be realized is missing. To this extent and only to this extent) the reproach that liberalism's talk of general interest or humanity remains caught in pure abstractions is correct. The structure and order of the whole are ultimately left to irrational forces: an accidental "harmony", a "natural balance." The plausibility of liberalist rationalism thus ceases immediately when, with the intensification of social conflict and economic crises, general "harmony" becomes increasingly improbable. At this point liberalist theory must grasp at irrational justifications. Rational critique gives up; it is all too readily prepared to acknowledge "natural" privileges and favors. The idea of the charismatic, authoritarian leader is already preformed in the liberalist celebration of the gifted econonic leader, the "born" executive. 39

As an alternative to instrumental reason, Marcuse attempts to revive the concept of a human essence as constructive of true rationality. This is a complex of historical memory, composed of suffering, domination, and violence, future potentiality, understood as the possibilities for freedom and happiness under the advanced productive capabilities which capitalism suppresses, and the opportunities of activity in the present, which both redeem the past and create the future. The most significant activity for Marcuse is sexual. It opposes the habits of renunciation imposed by bourgeois society, which Marcuse names affirmative culture.

By affirmative culture is meant that culture of the 
bourgeois epoch which led in the course of its own development to the segregation from civilization of the mental and spiritual world as an independent realm of value that is also considered superior to civilization. Its decisive characteristic is the assertion of a universally obligatory, eternally better and more valuable world that must be unconditionally affirmed: a world essentially different from the factual world of the daily struggle for existence, yet realizable by every individual for himself "from within", without any transformation of the state of fact. It is only in this culture that cultural activities and objects gain that value which elevates them above the everyday sphere. Their reception becomes an act of celebration and exaltation. $4 \emptyset$

Marcuse proposes instead of this culture of abstraction, privacy, and interiorization, a concrete, social, and sensuous one. In Marcuse's critique, sexual happiness has an absolutely subversive nature. Class relationships can only endure as cold spirituality or incomplete, frustrated, empty forms of gratification. Capitalist society transforms sensual pleasure into a bad instrumentality, into the discipline of marriage, into procreation for pusposes of production, into forms of labor.

The unpurified, unrationalized release of sexual relationships would be the strongest release of enjoyment as such and the total devaluation of labor for its own sake. No human being could tolerate the tension between labor as valuable in itself and the freedom of enjoyment. The dreariness and injustice of work conditions would penetrate explosively the consciousness of individuals and make impossible their peaceful subordination to the social system of the bourgeois world. 41

I want to proceed now to examine Reich's formulation of the concept of the genital character in relation to all these contexts - to the tendency of his generation to act out and project aggression, to the erotic, authoritarian, 
communal idealism of the youth movement, to the cultural values of natural forces and undifferentiated action, and to the psychoanalytic critique of fascism in terms of normative and autonomous ethics and liberating energies. Again, I want to suggest that whatever contradictory attitudes inform Reich's concept, basic motives of sympathy, freedom, and redemption are suggested by its historical situation and are signified by the formal qualities of Reich's writing.

In this review so far, the genital character has referred to Reich's clinical discovery that his patients' histories of genital primacy in childhood were a precondition for cure; to his endeavors to enable his patients to express themselves biologically, authentically, from the core of their being, in the autonomic undulations of orgasm; and to his typology of the characteristics of plague-ridden versus healthy individuals. Let me cite one last elaboration of the concept:

The genital character has a solid narcissistic foundation. In the neurotic character, on the other hand, the feeling of impotence forces the ego to make compensations of a narcissistic nature. The contemporary conflicts, permeated with irrational motives, make it impossible for the neurotic character to reach rational decisions.....

sexually unsatisfied and incapable of being satisfied, the neurotic character is finally forced either into asceticism or into rigid monogamy....

Upon brief reflection, we see that the empirical discovery of the above mechanisms becomes the basis for a revolutionary critique of all theoretically based systems of morals.... We can briefly state that to the extent that society makes possible the gratification of needs and the transformation of the corresponding human structures, the moral regulation of social life will fall away.... More simply expressed, what this all means is that the man whose sexual as well as primitive biological and cultural needs 
are satisfied does not require any morality to maintain self-control. But the unsatisfied man, suppressed in all respects, suffers from mounting inner excitation that would cause him to tear everything to pieces if his energy were not partially held in check and partially consumed by moralistic inhibitions....

The discussion of the broader consequences of sexeconomy and the analytic theory of character will not be able to evade these questions unless, at the sacrifice of its natural scientific prestige, it prefers to pull in the reins at the artificially erected boundary between what is and what should be. 42

Noteworthy, here, is the series of identity statements and implications. These include linking impotence with the inability "to reach rational decisions"; sadism and destructive urges with monogamy and morals; "the gratification of needs" and sexuality with social change and destruction of the state; nature with goodness; and the integrity of science with the utopian future. What this signifies is Reich's transformation and integration of a number of dominant cultural attitudes. Although built on clinical evidence, the statements do not represent anything like empirical proof. The implication that monogamy and abstinence mechanically produce irrationality might be true in certain case histories, but is absurd in general. Indeed, the suggestion seems authoritarian, an ironic abuse of sexual freedom, a peculiar projection, a lack of tolerance for individual wants, needs, and options. His demand that moral judgment be replaced by behavior regulated by sexual drives might appear an extreme mystification, similar to Volkish appeals to nature and activism. But 
considered in the context of other psychosexual critiques of politics, a different meaning emerges. It is clear that Reich's statements derive from an utopian identity of nature and reason, the human body and social instincts. Reich has found in his clinical experience hints that autonomous reason is validated in the complementary autonomous processes of nature and desire. These identities represent an overcoming of the irrational, dominating aspects of his milieu, in a linkage of nature and science to a transcendent reason and goodness.

A brief look at the context of Reich's total oeuvre, at The Mass Psychology of Fascism, for example - originally published in 1933 like Character Analysis, and also revised and enlarged into the 1940's - makes clear that these impulses toward freedom are not only formal ones, locked inside Reich's language or mode of argument. Reich is often the most powerful, clear, didactic champion of the broadest conception of freedom. The Mass Psychology is less a clinical work and more a sociological one. Consequently, Reich gives his basic political direction its clearest statement here. The Mass psychology also presents the reader with a series of identity statements. They are not merely formal significations of liberation, but powerful didactic ones, convincing images of a real, material liberating activity.

Reich begins with a statistical identity between the 
German lower middle class and the electoral support for Hitler. He balances this with a consideration reminiscent of Bataille - that there are "not only regressive but also very energetic progressive social forces in the rebelliousness of the lower middle classes." (page 6). Reich suggests this two-sidedness is in the nature of consciousness. Formed in childhood, it consequently lags behind immediate needs, it is a conservative force; it includes an "ambivolant attitude toward authority rebellion against it coupled with acceptance and submission."43 This formulation, similar to Gilbert's, Reich connects to a sociological identity between the patriarchal authoritarian family and the authoritarian state. Sexual repression, bourgeois morality, the father's discipline, the compulsive suppression of childhood masturbation and adolescent love, all reproduce "an authoritarian social system in the structure of its members." 44 Sexual repression results both in the loss of self and self-confidence as well as sadistic habits of domination toward oneself and others - honor, duty, bravery, a whole pattern of violent renunciation.

Reich proposes an identity relationship counter to this, and similar to Marcuse's, based on free sexual activity. "Sexual desires naturally urge a person to enter into all kinds of relations with the world, to enter into close contact with it in a variety of forms."45 These 
subsume love, nature, and social immunity into a pattern of self-reflecting and self-generating acts of reason, pleasure, and freedom. For example, rational measures of reform "will result spontaneously, if only the basic principle of sexual affirmation and the social protection of childhood and adolescent sexuality is adhered to." 46 In brief, "to define freedom is to define sexual health."47 Like Horkheimer, this habit of identity statements enables Reich at certain moments to express the most unequivocal demands for freedom. "We wean the genuine freedom of personal and social development, the freedom to face life without fear, freedom from all forms of economic suppression, freedom from reactionary inhibitions of development; in short, the free self-administration of libido." 48

And in the end, this is a real identity of nature and human psychic life and activity authenticated by the most utopian demand. "If there should ever be a society in which all the cases for freedom fade away; then man will have finally overcome his biological and social deformity and have achieved genuine freedom. Not until man acknowledges that hs is fundamentally an animal, will he be able to create a genuine culture." 49

This is again evidence of Reich's basic intention throughout his work to establish an absolute, thoroughgoing identification of nature and freedom. And $I$ think it is 
significant that here, again, Reich imagines this identity relationship as knowledge that resides in silence; it is the soothing of all cries of discontent, the fulfillment in quiet of the final demand for liberation. 
1. Peter Loewenberg, "The Psychohistorical Origins of the Nazi Youth Cohort", American Historical Review 76 (1971), p. 1465 .

2. Ibid., p. 1470 .

3. Ibid., p. 1458.

4. Ibid., pp. 1473, 1487.

5. Ibid., p. 1463 .

6. David Rodnick, Postwar Germans: An Anthropologist's Account (New Haven, 148), p. 5 .

7. Ibid., p. 18 .

8. Ibid.

9. Ibid., p. 61 .

10. Walter $\mathrm{z}$. Laqueur, Young Germany: A History of the German Youth Movement (New York, 1962), p. xx.

11. Ibid., p. 4.

12. Hermann Goering quoted in George L. Waite, Vanguard of Naziism (Cambridge, 1952), p. 29.

13. Ibid., p. 29.

14. Ibid., p. 56 .

15. Erich Fromm, Escape from Ereedom (New York, 1941), pp. $155-156$.
16. Ibid., p. 279.
17. Ibid., p. 19.
18. Ibid., p. 101 
19. G. M. Gilbert, The Psychology of Dictatorship: Based on an Examination of the Leaders of Nazi Germany (New York, $\overline{1950)}$, p. 40 .

$$
\begin{aligned}
& \text { 20. Ibid., p. } 62 . \\
& 21 \text {. Ibid., p. } 132 . \\
& 22 \text {. Ibid., p. } 252 .
\end{aligned}
$$

23. Erik H. Erikson, "Wholeness and Totality - A psychiatric Contribution", in Totalitarianism: Proceedings of a conference Held at the American Academy of Arts and Sciences, March 1953, edited by Carl J. Friedrich (New York), p. 159 .

$$
\begin{aligned}
& \text { 24. Ibid., pp. 160-161. } \\
& \text { 25. Ibid., p. } 170 \text {. }
\end{aligned}
$$

26. Georges Bataille, "The Psychological structure of Fascism", translated by Carl R. Lovitt, New German Critique $16(1979)$, p. 66.

27. Ibid., p. 70 .

28. Ibid., p. 71.

29. Ibid., p. 70 .

30. Ibid., p. 78 .

31. Ibid., p. 85 .

32. Ibid., p. 87.

33. Max Horkheimer, Eclipse of Reason (New York, 1974), p. 21 .

34. Horkheimer, "Authority and the Family", in Critical Theory: Selected Essays, translated by Matthew $J$. O'Connell, (New York, 1982), pp. 55-56.

35. Horkheimer, Eclipse of Reason, p. 111.

36. Ibid., p. 112.

37. Horkheimer and Theodor W. Adorno, Dialectic of Enlightenment, translated by John Cumming (New York, 1982), p. 14 . 
38. Herbert Marcuse, Negations: Essays in Critical Theory, translated by Jeremy J. Shapiro (Boston, 1968), p. 14.

39. Ibid., p. 18 .

40. Ibid., p. 95.

41. Ibid., p. 187.

42. Wilhelm Reich, Character Analysis, pp. 184-185.

43. Wilhelm Reich, The Mass Psychology of Eascism,

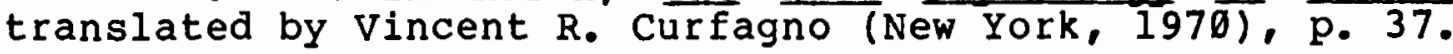

44. Ibid., p. 53.

45. Ibid., p. 56 .

46. Ibid., p. 352.

47. Ibid., p. 346 .

48. Ibid., p. 331.

49. Ibid., p. 345. 
CHAPTER V

\section{CONCLUSION}

In this exercise I have attempted to derive historical meaning from a problematic text. Using the formal strategies of I. A. Richards and Roland Barthes, and the broadest sense of meaning elucidated in modern historical methodologies, I have related a personal reading of disjunctures in Character Analysis to the general struggle in this century to formulate a theory of liberation. Meaning emerges from the two-sided nature of Reich's work. Both his personal sympathies and the edges of his argument those formal indications of liberation which allow freedom of self-consciousness, discretion for the reader within the spaces created by contradictions - compete with the authoritarian tendencies of his age and of his own personality. In the end, the eccentricities of the text defy any movement toward restrictions, rules of proper discourse, potential for instrumental domination, that may be otherwise present in Reich's theory. This becomes clearest in Reich's concept of genital character, which is not so much a list of proper, restrictive traits, as a simple identity of human needs and nature, itself, as an autonomous goodness. 
I began this essay by noting a tendency of historians to view their work as illuminated by the needs of the present. In conclusion, I want to mention a recent criticism of Reich's legacy. In The History of Sexuality, Michel Foucault explains why Reich's tactic of breaking through the knot of class contradictions with the weapon of sexual practices failed over the last half century.

Thus between the two world wars there was formed, around Reich, the historico-political critique of sexual repression. The importance of this critique and its impact on reality were substantial. But the very possibility of its success was tied to the fact that it always unfolded within the deployment of sexuality, and not outside or against it. The fact that so many things were able to change in the sexual behavior of Western societies without any of the promises or political conditions predicted by Reich being realized is sufficient proof that his whole sexual "revolution", this whole "anti-repressive" struggle, represented nothing more, but nothing less - and its importance is undeniable - than a tactical shift and reversal in the great development of sexuality. But it is also apparent why one could not expect this critique to be the grid for a history of that very development. Nor the basis for a movement to dismantle it. 1

Foucault seems to assert that the secret to crucial relationships of power lies not in the mysteries of the orgasm, but in the pleasures of language; that sexuality is not so much a matter of bodies - their functions and nature - as of ways of talking and imaging; that relationships and instruments of domination remain in discourse and dispersions of knowledge, irregardless of the quality of erotic practices. Reich, I believe, has the better argument. By linking the concept of liberation with an irreducible, non-discursive core of biologic experience, he 
preserves its integrity as a total utopian demand. Sexuality becomes the domain of unified reason, nature, and potentiality. Reich's formulation, his language, is a sly suggestion, a promise unfulfilled; it represents a residue of desire which subverts any reconciliation to class formations by signifying a whole new world. 


\section{CHAPTER V}

\section{ENDNOTES}

1. Michel Foucault, The History of sexuality: Vol. I, An Introduction, translated by Robert Huxley (New York, $1980)$, p. 131 . 


\section{BIBLIOGRAPHY}

\section{PRIMARY SOURCES}

Bataille, Georges. "The Psychological structure of Fascism." Translated by Carl R. Lovitt. New German Critique 16 (1979), pp. 64-87.

Erikson, Erik H. "Wholeness and Totality - A Psychiatric contribution." In Totalitarianism: proceedings of a Conference Held at the American Academy of Arts and Sciences, March 1953. Edited by Carl J. Friedrich. New York: Grosset and Dunlap.

Freud, Sigmund. "Papers on Metapsychology (1915)." In The Standard Edition of the Basic Writings of sigmund Freud. Edited and translated by James strachey. Volume xiv. London: The Hogarth Press and the Institute of Psycholanalysis, 1957.

From, Erich. Escape from Freedom. New York: Holt, Rinehart, and winston, 1941.

Gilbert, G. M. The Psychology of Dictatorship: Based on an Examination of the Leaders of Nazi Germany. New York: The Ronald press, 1950.

Horkheimer, Max. "Authority and the Family." In critical Theory: Selected Essays. Translated by Matthew J. O'Connell. New York: Continuum, 1982.

- and Adorno, Theodor W. Dialectic of Enlightenment. Translated by John Cumming. New York: Continuum, 1982 .

- Eclipse of Reason. New York: The Seabury Press, 1974 .

Marcuse, Herbert. An Essay on Liberation. Boston: Beacon Press, 1969.

- Negations: Essays in Critical Theory. Translated by Jeremy J. Shapiro. Boston: Beacon Press, 1968.

Reich, Wilhelm. Character Analysis. Translated by Vincent R. Carfagno. New York: Simon and Schuster, 1972. 
The Mass Psychology of Fascism, Translated by Vincent R. Carfagno. New York: Farrar, Straus and Giroux, 1970 .

- People in Trouble: Volume Two of The Emotional plague of Mankind. Translated by Philip Schmitz. New York: Farrar, Straus, and Giroux, 1976 .

\section{INTERPRETATIVE SOURCES}

Barthes, Roland. "From Work to Text." In Image, Music, Text. Translated by Stephen Heath. New York: Hill and Wang, 1977.

"Introduction to the structural Analysis of Narratives." In A Barthes Reader. Edited by Susan Sontag. Translated by Stephen Heath. New York: Hill and wang, 1982.

- The Pleasure of the Text. Translated by Richard Miller. New York: Hill and Wang, 1975.

Cohen, sande. "Structuralism and the writing of Intellectual History." History and Theory 17 (1978), pp. 173-206.

Collingwood, R. G. The Idea of History. Oxford: Oxford University Press, 1946. $\frac{\text { Encyclopedia }}{\text { Wilhelm.n }}$ of Philosophy, lst ed., s.v. "Reich,

Femia, Joseph V. "An Historicist Critique of "Revisionist" Methods for studying the History of Ideas." History and Theory 20 (1981), pp. 113-134.

Foucault, Michel. The Archaeology of Knowledge and the Discourse on Language. Translated by A. M. SheridanSmith. New York: Pantheon Books, 1972.

The History of Sexuality: Vol. I, An Introduction. Translated by Robert Huxley. New York: Vintage Books, 1980 .

Holland, Norman H. The Dynamics of Literary Response. New York: Oxford University press, 1968.

Jacoby, Russell. Social Amnesia: A Critique of Conformist psychology from Adler to Laing. Boston: Beacon 
Press, 1975.

Jay, Martin. The Dialectical Imagination: A History of the Frankfurt school and the Institute of Social Research, 1923-1950. Boston: Little, Brown, and Co., 1973.

- Marxism and Totality: The Adventures of a Concept from Lukacs to Habermas. Berkeley and Los Angeles: University of California Press, 1984.

LaCapra, Dominick. "Rethinking Intellectual History and Reading Texts." History and Theory 19 (1980), pp. 245-276.

Laqueur, Walter $Z$. Young Germany: A History of the German youth Movement. New York: Basic Books Pub. Co., Inc., 1962 .

Loewenberg, Peter. "The psychohistorical Origins of the Nazi Youth Cohort." American Historical Review 76 (1971), pp. 1457-1502.

"Psychohistorical Perspectives on Modern Germany History." Journal of Modern History 47 (1975), pp. 229-279.

Mosse, George L. The Crisis of German Ideology: Intellectual origins of the Third Reich. New York: Grosset and Dunlap, 1964.

Reich, Ilsa ollendorff. Wilhelm Reich: A Personal Biography. New York: St. Martin's Press, 1969.

Reich, Peter. A Book of Dreams. New York: Harper and Row, Publishers, 1973 .

Richards, I. A. practical Criticism: A Study of Literary Judgment. New York: Harcourt, Brace, and World, Inc., 1929.

Rodnick, David, Postwar Germans: An Anthropologist's Account. New Haven: Yale University Press, 1948.

Sharaf, Myron. Fury on Earth: A Biography of Wilhelm Reich. New York: St. Martin's Press/Marek, 1983.

Skinner, Quentin. "Meaning and Understanding in the History of Ideas. Bistory and Theory 8 (1969), pp. 3-53.

Waite, George L. Vanquard of Nazism. Cambridge: Harvard University Press, 1952. 
Walsh, W. H. "The Causation of Ideas." History and Theory 14 (1975), pp. 186-199.

Weingartner, Rudolph H. "Some Philosophic Comments on Cultural History." History and Theory 7 (1968), pp. 38-59.

White, Hayden V. Metahistory: The Historical Imagination in Nineteenth Century Europe. Baltimore and London: The Johns Hopkins Press, 1973. 